\title{
LATE QUATERNARY CLIMATIC CYCLES AS RECORDED IN SEDIMENTS FROM THE ANTARCTIC CONTINENTAL MARGIN
}

\author{
Hannes Grobe and Andreas Mackensen
}

\author{
Alfred Wegener Institute for Polar and Marine Research, D-2850 Bremerhaven, Germany
}

To reveal the late Quaternary paleoenvironmental changes at the Antarctic continental margin, we test a lithostratigraphy adjusted to a stable isotope record from the eastern Weddell Sea. The stratigraphy is used to produce a stacked sedimentological data set of 11 sediment cores. We derive a general model of glaciomarine sedimentation and paleoenvironmental changes at the East Antarctic continental margin during the last two climatic cycles $(300 \mathrm{kyr})$. The sedimentary processes considered include biological productivity, ice rafting, current transport, and gravitational downslope transport. These processes are controlled by a complex interaction of sea level changes and paleoceanographic and paleoglacial conditions in response to changes of global climate and local insolation. Sedimentation rates are mainly controlled by ice rafting which reflects mass balance and behavior of the Antarctic ice sheet. The sedimentation rates decrease with distance from the continent and from interglacial to glacial. Highest rates occur at the very beginning of interglacials, i.e., of oxygen isotope events 7.5,5.5, and 1.1, these being up to 5 times higher than those during glacials. The sediments can be classified into five distinct facies and correlated to different paleoenvironments: at glacial terminations (isotope events 8.0,6.0, and 2.0), the Antarctic cryosphere adjusts to new climatic conditions. The sedimentary processes are controlled by the rise of sea level, the destruction of ice shelves, the retreat of sea ice, and the recommenced feeding of warm North Atlantic Deep Water (NADW) to the Circumpolar Deep Water (CDW). During peak warm interglacial periods (at isotope events $7.5,7.3,5.5$, and 1.1), the CDW promotes warmer surface waters and thus the retreat of sea ice which in turn controls the availability of light in surface waters. At distinct climatic thresholds, local Insolation might also influence sea ice distribution. Primary productivity and bioturbation increase, the calcite compensation depth rises, and carbonate dissolution occurs in slope sediments also in shallow depth. Ice shelves and coastal polynyas favor the formation of very cold and sahne Ice Shelf Water which contributes to bottom water formation. During the transition from an interval of peak warmth to a glacial episode (isotope stages 7.2-7.0 and 5.4-5.0), the superimposition of both intense ice rafting and reduced bottom currents produces a typical facies which occurs with a distinct lag in the time of response of specific sedimentary processes to climatic change. With the onset of a glacial episode (at isotope events 7.0 and 5.0) the Antarctic ice sheet expands owing to the lowering of sea level with the extensive glaciations in the northern hemisphere. Gravitational sediment transport becomes the most active process, and sediment transfer to the deep sea is provided by turbidity currents through canyon Systems. During Antarctic glacial maxima (isotope stages 6.0 and 4.0-2.0) the strongly reduced input of NADW into the Southern Ocean favors further advances of the ice shelves far beyond the shelf break and the continuous formation of sea ice. Below ice shelves and/or closed sea ice coverage contourites are deposited on the slope.

\section{INTRODUCTION}

Antarctica represents a unique sedimentary environment. The Antarctic Ocean is covered for most of the year by sea ice which, together with the presence of a huge continental ice sheet, controls nearly all environmental conditions, resulting in markedly different sedimentation processes. With its extensive ice shelves in the Weddell Sea and the Ross Sea. the Southern Ocean is one of the Earth's principal sources of oceanic bottom waters and plays a key role in governing global oceanic circulation and climate. Concerning the sedimentation processes at the Antarctic continental margin, the understanding of the behavior of ice shelves is crucial.

Research on the Cenozoic cryospheric development of Antarctica was strengthened during recent years by the Ocean Drilling Project (ODP). The long-term record since Cretaceous time was reconstructed on southern Indian Ocean ODP legs 119 and 120, and particularly on legs 113 and 114 into the subpolar and polar South Atlantic. Site 693, drilled during Leg 113 [Barker et al., $1988,1990]$, is located in our investigation area off Cape Norvegia in the eastern Weddell Sea (Figure 1). Investigations of Miocene/Pliocene sediments from the South Atlantic have focused on glacial evolution and paleoceanographic changes during the Neogene [Abelmann et al., 1990; Hodell and Ciesielski, 1990]. During the last decade there was an extensive sampling program carried out by gravity and piston coring from $\mathrm{R} / \mathrm{V} \mathrm{Po}_{\mathrm{O}}$ - 


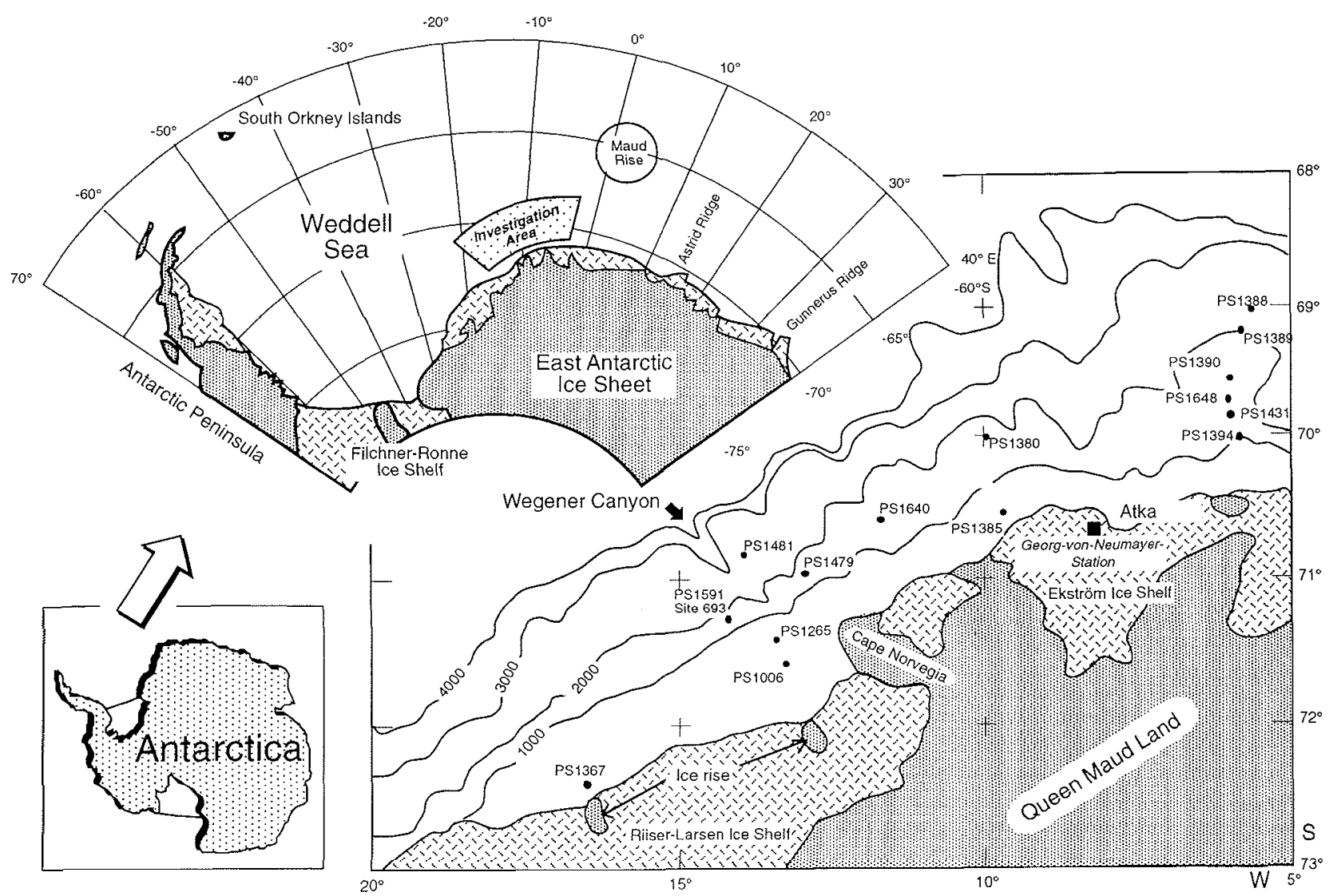

Fig. 1. Investigation area at the Antarctic continental margin in the eastern Weddell Sea. Four gravity cores fromthe shelfand 11 cores fromthe slope have been investigated. Core PS1591 is located at the same position as ODP Site 693, completing its undisturbed uppermost Quaternary sequence. Canyons, such as the Wegener Canyon in the investigation area, play an important role in transport processes from the shelfinto the deep sea. Further sites, where similar sedimentary records occur, are indicated at the continental margin south of the South Orkney Islands, at Maud Rise, and around Astrid and Gunnerus ridges.

larstern mostly focusing on the Quaternary sediment sequence of the Atlantic part of the Southern Ocean.

The distribution of Quaternary sediments in the Southern Ocean results from a complex interaction of glaciological, oceanographic, and biological processes. Therefore the first marine geological work on Quaternary sediments in this area focused on sedimentation processes [Anderson, 1972; Anderson et al., 1979, 1983b; Elverhфi, 1981; Elverhфi and Roaldset, 1983]. Several models were established regarding those processes to explain the cryospheric depositional processes in the marine environment and the behavior of the Antarctic ice sheet on the basis of the analysis of Pleistocene sediments [Anderson et al., $1983 a$; Domack, 1982; Drewry and Cooper, 1981; Kellogg and Kellogg, 1988; Orheim and Elverhфi, 1981]. Only a few models were developed concerning paleoclimatic and paleoceanographic reconstructions [Kellogg et al., 1979; Weaver, 1973]. More recently, sedimentation pat- terns on the continental margin around the Weddell Sea were investigated in order to reveal environmental variations of the hydrosphere and cryosphere and to unravel the Quaternary climatic history of Antarctica [Grobe, 1986; Haase, 1986; Futterer et al., 1988; Cordes, 1990; Futterer and Melles, 1990; Grobe et al., 1990 b; Mackensen et al., 1990; Melles, 19911.

Our results, although based on the investigation of the late Quaternary deposits from the eastern Weddell Sea only, contribute to the understanding of the late Neogene glacial evolution of Antarctica as a whole. Records similar to those described in this paper were found in sediments of the Antarctic continental margin between South Orkney and Gunnerus Ridge, covering nearly a third of the Antarctic coast line. Stratigraphic problems were solved by the development of a lithostratigraphy which allows correlation of lithologic changes with a stable isotope record. The lithostratigraphy was applied toward the late Pleistocene chronology. We used the 
$\delta^{18} \mathrm{O}$ record of Core PS1388, measured on both planktonic and benthic foraminifera, which currently is the only record from the area substantially south of the Polar Front that can be correlated with the global isotope stratigraphy [Mackensenet al., 1989] (Figure 2).

A high-resolution stratigraphy and an extended sedimentological data set of 11 cores with inferred high sedimentation rates and a dense sample spacing allow stacking of sedimentological parameters. The Parameter stacks, in correlation with global climate and local insolation, were used to develop a detailed model of the sedimentary environment during a glacial and an interglacial stage. Special emphasis in the interpretations is given to the environmental changes due to sea ice cover and movements of the Antarctic ice edge in response to the two pronounced Quaternary climatic cycles covering the last $300 \mathrm{kyr}$.

\section{MATERIAL AND METHODS}

Sediments were recovered by gravity corer during Polarstern expeditions ANT IV/3 [Futterer, 1987], ANT V/4 [Millerand Oerter, 1990], and ANT VI/3 [Futterer, 1988 ] on profiles perpendicular to the Antarctic continental margin between $9^{\circ}$ and $15^{\circ} \mathrm{W}$. Eleven cores from the slope with a total length of $113 \mathrm{~m}$ were chosen for a detailed interpretation of the stratigraphic and sedimentological data sets because of good resolution and paleoenvironmental signals during the last $300 \mathrm{kyr}$ (Figure 1, Table 1). The following interpretations will focus on the last two climatic cycles (indicated by bold lines in Figure 3) even if bottom ages of some of the cores can be much higher. Core sites were mainly situated in the middle of the continental slope terrace, in water depth between 2000 and $2800 \mathrm{~m}$.

Cores PS1394, PS1431, PS1648, PS1390, PS1389, and PS1388 were located on a S-N profile on the slope off Atka Iceport with slightly increasing water depth between 2000 and $2500 \mathrm{~m}$ (Figure 1). In contrast, cores PS1591, PS1479, PS1640, and PS1380 were situated on a line mostly parallel to both the isobaths and the ice edge, resulting in an almost constant distance to the shelf. Core PS1481 was located further north off Cape Norvegia and has a basal age of up to $4 \mathrm{~m}$.y. Owing to its proximity to the Wegener Canyon, several hiatuses are present, but the uppermost sequence of the last 300 kyr remained undisturbed. Gravity Core PS1591 was located at the same position and complemented Site 693 by recovering undisturbed the uppermost Quaternary sedimentary sequence. With the short cores PS1006, PS1265, PS1367, and PS1385 on the shelf (Figure 1, Table 1), only the Holocene sediments were recovered.

Cores were sampled with a mean sampling interval of $10 \mathrm{~cm}$, providing stratigraphic resolution of between 1000 and 10,000 years, depending on sedimentation rates. In total, 1265 samples were taken (Table 1) and analyzed for carbon, grain size, clay mineralogy, and components of the coarse fraction. Sediment structure and ice-rafted debris were investigated on $\mathrm{X}$ radiographs of 1-cm-thick sediment slices. The gravel fraction $>2 \mathrm{~mm}$ was counted in the radiographs and expressed as numbers per $10 \mathrm{~cm}^{3}$ [Grobe, 1987]. Other sedimentological data were produced using standard methods as described by Grobe et al. [1990b]. The most important parameters (carbonate, radiolaria, illite, silt) of each core are plotted versus depth in Figure 3. Core PS1648 was chosen to show all parameters in detail (Figure 4). Stable oxygen and carbon isotope measurements were made on planktonic foraminiferal tests of sinistrally coiled Neogloboquadrina pachyderma with samples containing on average six specimens from the 125- to $250-\mu \mathrm{m}$ size fraction. The foraminifera were measured using an automatic carbonate preparation device connected on line to a Finnigan MAT 251 mass spectrometer.

The peak warm times of interglacials correspond to the isotopic events 1.1, 5.5, 7.3/7.5, 9.3, and 11. In Antarctic glaciomarine sediments, only the facies deposited during these climatic events differ significantly from the rest of the Pleistocene deposits. Therefore when dealing with terms like "glacial" and "interglacial" a difference between a chronostratigraphically defined interglacial (e.g., stage 5) and the occurrence of a specific sedimentological facies (e.g., event 5.5), interpreted as being deposited during an interglacial, has to be kept in mind.

\section{AREA OF INVESTIGATION}

\section{Physiography}

The Antarctic continental margin in the eastern part of the Weddell Sea has been surveyed with swath sonar echo-sounding systems during several Polarstern expeditions [e.g., Fiitterer, 1987, 1988; Miller and Oerter, 1990]. In particular, the bottom topography of the area off Queen Maud Land between $16^{\circ} \mathrm{W}$ and $2^{\circ} \mathrm{W}$ is well known. The slope can be divided into five major characteristic morphological units. The partly overdeepened continental shelf has a maximum water depth of between 300 and $400 \mathrm{~m}$ and a distinct shelf break. This is followed seaward by a very steep and narrow upper continental slope with inclinations of up to $16^{\circ}$. The transition to a gently inclined midslope bench occurs from west to east in decreasing water depths between $1700 \mathrm{~m}$ and $1200 \mathrm{~m}$. The bench is 50 to $100 \mathrm{~km}$ wide, dipping seaward at $1.5^{\circ}$ to about $3000-\mathrm{m}$ water depth. The lower slope is characterized by the steep, clifflike Explora Escarpment [Hinz and Krause, 1982; Henriet and Miller, 1990], locally showing maximum slope inclinations of $30^{\circ}$ [Fiittereret al., 1990]. The continental rise ends in the Weddell Abyssal Plain at about 4400-m water depth.

The continental slope is deeply dissected by at least 


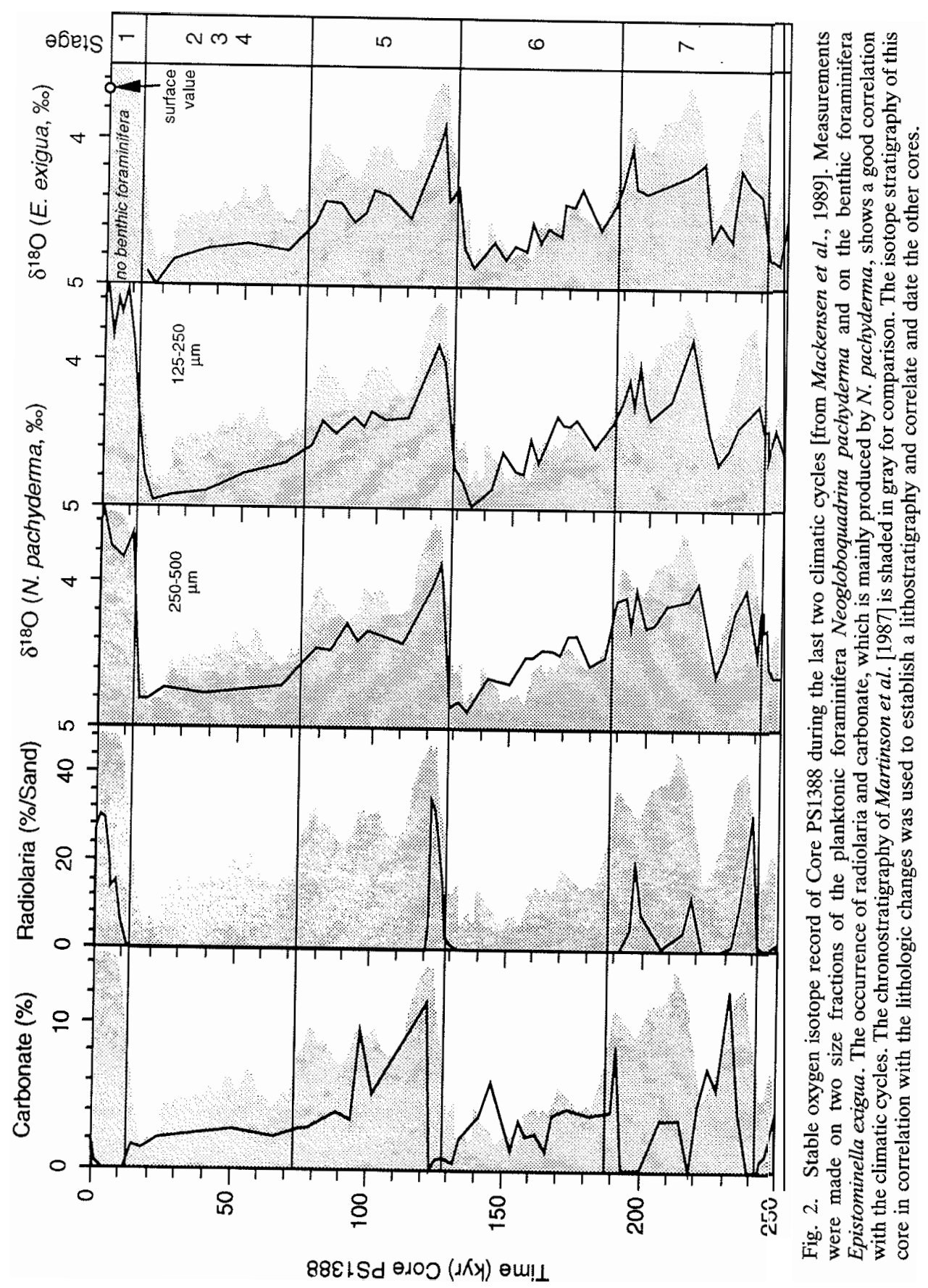


TABLE 1. Basic Data on the Sediment Cores Investigated

\begin{tabular}{|c|c|c|c|c|c|c|c|c|}
\hline $\begin{array}{l}\text { Core } \\
\text { Site }\end{array}$ & $\begin{array}{c}\text { Longitude, } \\
\text { deg }\end{array}$ & $\begin{array}{l}\text { Latitude, } \\
\text { deg }\end{array}$ & $\begin{array}{l}\text { Depth, } \\
\text { m }\end{array}$ & $\begin{array}{l}\text { Length of } \\
\text { Core, } \mathrm{cm}\end{array}$ & $\begin{array}{c}\text { No. of } \\
\text { Samples }\end{array}$ & $\begin{array}{c}\text { Bottom } \\
\text { Ages, kyr }\end{array}$ & $\begin{array}{c}\text { Sedimentation } \\
\text { Rate } \\
\text { Interglacial, } \\
\mathrm{cm} / \mathrm{kyr}\end{array}$ & $\begin{array}{c}\text { Sedimentation } \\
\text { Rate Glacial, } \\
\mathrm{cm} / \mathrm{kyr}\end{array}$ \\
\hline \multicolumn{9}{|c|}{ Sheij } \\
\hline PS1006 & -13.272 & -71.493 & 235 & 55 & 9 & Holocene & & \\
\hline PS1265 & -13.408 & -71.352 & 230 & 31 & 5 & Holocene & & \\
\hline PS1367 & -16.517 & -72.333 & 303 & 238 & 25 & Holocene & & \\
\hline PS1385 & -9.617 & -70.483 & 328 & 95 & 12 & Holocene & & \\
\hline \multicolumn{9}{|c|}{ Slope } \\
\hline PS1380 & -9.983 & -70.000 & 2060 & 945 & 100 & 450 & 5.8 & 0.7 \\
\hline PS1388 & -5.883 & -69.033 & 2517 & 1238 & 141 & 1000 & 5.2 & $\cdot 1.1$ \\
\hline PS1389 & -5.967 & -69.217 & 2259 & 909 & 93 & 410 & 4.2 & 0.5 \\
\hline PS 1390 & -6.383 & -69.617 & 2798 & 990 & 108 & 520 & 4.7 & 0.6 \\
\hline PS1394 & -6.667 & -70.083 & 1945 & 910 & 100 & 123 & 21.3 & 3.4 \\
\hline PS1431 & -6.570 & -69.817 & 2458 & 935 & 99 & 244 & 7.9 & 1.2 \\
\hline PS1479 & -13.404 & -70.549 & 2322 & 1180 & 118 & 2100 & 1.8 & 0.6 \\
\hline PS1481 & -13.963 & -70.830 & 2505 & 1076 & 154 & 3990 & 2.1 & 0.3 \\
\hline PS1591 & -14.555 & -70.834 & 2361 & 1220 & 153 & 2290 & 2.9 & 0.3 \\
\hline PS1640 & -11.657 & -70.339 & 2101 & 1020 & 111 & 390 & 6.8 & 1.5 \\
\hline PS1648 & -6.525 & -69.740 & 2531 & 863 & 88 & 340 & 6.8 & 1.1 \\
\hline
\end{tabular}

The shelf cores only recover the Holocene sediment sequence. The time included depends on sedimentation rates and the occurrence of hiatus. Sedimentation rates were calculated using a lithostratigraphy in correlation with an oxygen isotope stratigraphy.

one major submarine canyon system, i.e., the Wegener Canyon off Cape Norvegia (Figure 1) which was mapped by systematic bathymetric surveys [Fütterer et al., 19901. The tributary gullies of the canyon cut into the upper slope with the easternmost one continuing across the shelfand beneath the ice shelf. The formation of the canyon is structurally controlled by the sill of the Explora Escarpment and is considered to be of early late Miocene age [Barker et al., 1988]. During the Quaternary the canyon was particularly active during glacial episodes [Fütterer et al., 19901. This indicates that the canyon played a major role in gravitational downslope transport processes during the Pleistocene climatic cycles.

Of paramount importance for the understanding of the sedimentary processes in this area is detailed information about the slope morphology that is largely responsible for distinct sedimentary patterns and the accumulation of undisturbed Quaternary sediment sequences close to the continent. The Quaternary sequence on most parts of the terrace in the intercanyon areas is less affected by turbidites and mass flow events than is usually the case in this area [Wright and Anderson, 1982; Anderson et al., 1986]. At least during the last two climatic cycles, the flat part of the slope was not a source area for sediment gravity flows to the deep sea. Sediment supply to the abyssal plain was presumably restricted to canyon Systems like the Wegener Canyon during glacials. The importance of sediment gravity flow has to be taken into account in dealing with more long-term geological records. High sediment supply to form a fan, as described in the eastern Weddell Sea, apparently occurred before the development of the glacial shelf topography and during a more temperate glacial setting [Andersonet al., 19861.

In this part of the Weddell Sea, a broad terrace in the middle of the continental slope favors relatively undisturbed sedimentation and thus provides excellent conditions for paleoenvironmental interpretations of the late Quaternary climatic cycles. In addition, the sediments deposited in water depth ofless than $3500 \mathrm{~m}$ have a significant carbonate content because they are mostly deposited above the calcite compensation depth (CCD) and thus provide calcareous foraminifera for use in measuring stable isotopes [Mackensen et al., 19891.

\section{Modern Sediment Distribution Patterns}

The most important recent environmental conditions and sedimentological Parameters on shelf and slope of the study area were investigated in relation to the association of benthic foraminifera [Mackensen et al., 19901. The reconstruction of the distribution patterns of sediments and foraminifera were made on the basis of samples which were taken with a vented box corer, providing undisturbed surface material.

In general, the surface sediments at the eastern continental margin consist of silty and clayey muds with varying amounts of coarse sand and gravel. The highest values of sand and gravel were found on the shelf which is a different sedimentary environment compared with the conditions on the slope. On the shelf during settling, 
Carbonate (\%) Radiol. (\%/S) Illite (\%) Silt (\%) Carbonate (\%) Radiol. (\%/S) Illite (\%) Silt (\%)
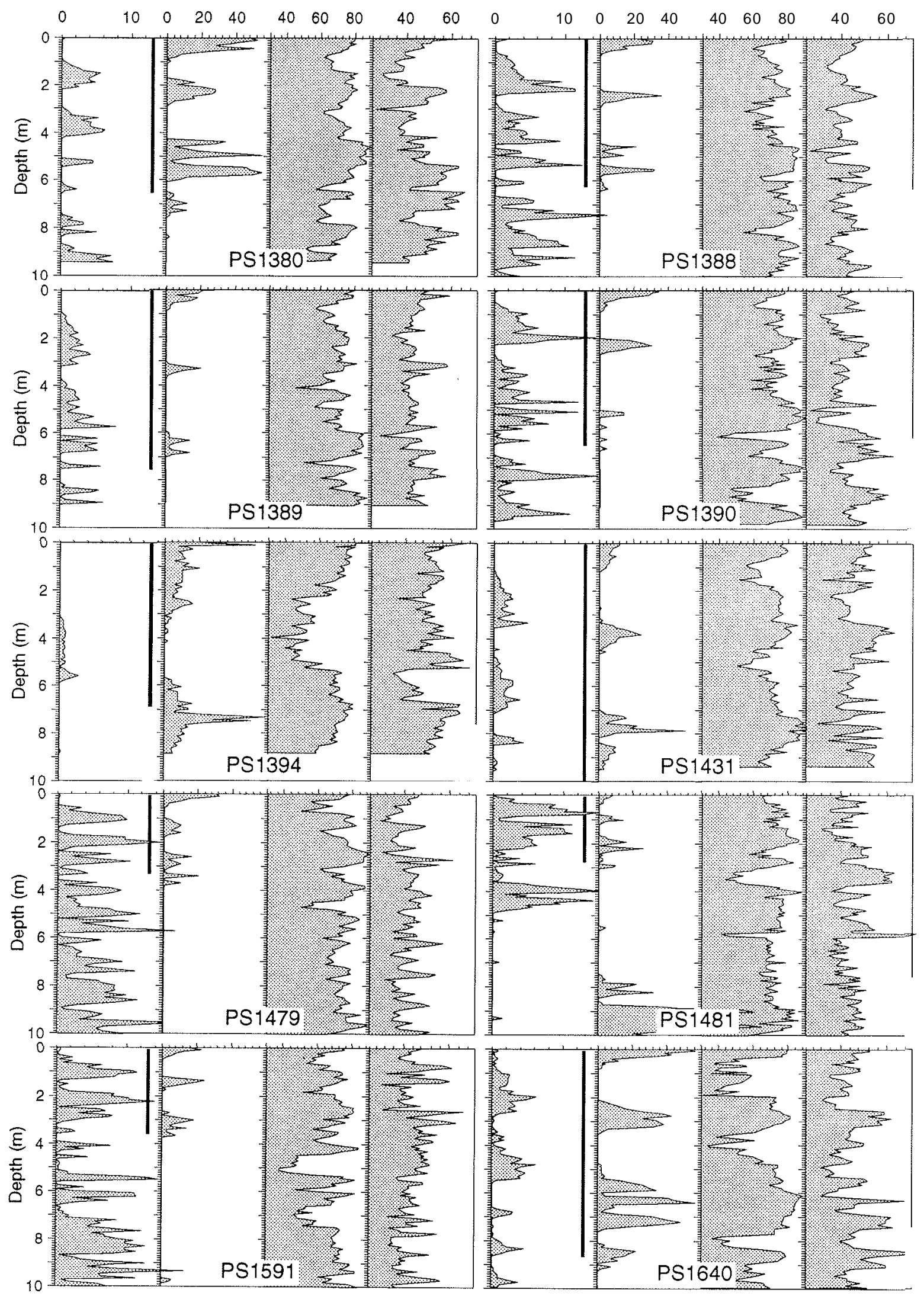
some of the clay and fine silt are kept in suspension and transported by the Antarctic Coastal Current (ACC), leading to an enrichment of the coarser grades in the bottom sediments [Elverh $\phi i$ and Roaldset, 19831. Biogenic particles constitute an integral part of the glaciomarine deposits. Sponge spicules are abundant in the shelf sediments where an extensive sponge fauna was observed; carbonate is mainly produced by bryozoans [Voss, 1988]. Sedimentation rates are relatively low (1-5 cm/kyr) [Elverh $\phi i, 1981$; Elverh $\phi i$ and Roaldset, 19831.

Sediment echo soundings on the upper steep slope, well below the shelf edge, provide evidence that the slope is covered by a coarse, presumably residual sediment. The current-winnowed silts and clays are entrained by contour currents and transported along the continental slope [Anderson et al., 1979]. Down to a depth of about $1600 \mathrm{~m}$, the sand-size fraction exceeds $40 \%$. On the midslope bench and the lower slope, down to the abyssal plain, the mud content $(<63 \mathrm{pm})$ exceeds $50 \%$ of the bulk sediment; gravel and sand are also present, but only in minor proportions.

Clay minerals are represented by chlorite, illite, and smectite. Because of the absence of any chemical weathering processes on the continent, kaolinite is only found in traces in all Quaternary sedirnents $(<5 \%$, e.g., PS1648, Figure 4) and is of no paleoclimatic significance. The kaolinite found may have been produced by weathering during an earlier warm humid climate and locally stored in ancient sedimentary rocks.

The carbonate content of the surface sediments can be grouped in four depth zones. On the shelf, a carbonate content of up to $9.5 \%$ of the bulk dry sediment consists of bryozoans, bivalves, gastropods, brachiopods, solitary corals, and benthic foraminifera. At the shelf break and on the upper slope, down to about 2000 $\mathrm{m}$, the carbonate content never exceeds $1 \%$. This depth zone corresponds to the range of the core of the Weddell Deep Water (WDW), which is a branch of the Circumpolar Deep Water (CDW) [Foldvik et al., 1985; Anderson, 19751. On the slope terrace, between 2000 and $3500 \mathrm{~m}$, carbonate content is between 3 and $13 \%$. This is almost exclusively produced by planktonic foraminifera, supplemented by some other marine organisms. No detrital carbonate was found. The recent depth of the CCD is $-4000 \mathrm{~m}$. Below this depth, virtually no carbonate was found in the surface sediments [Anderson, 1975; Mackensen et al., 19901. Siliceous particles, consisting of radiolaria, diatoms, sponge spicules, and

Fig. 3. (Opposite) Percentages of carbonate, radiolaria (percent of the sand fraction), illite, and silt in the individual cores plotted versus depth. Bold lines indicate the range of the last $300 \mathrm{kyr}$ which was included in our investigations. Alternating occurrence of carbonate and silica can be observed in each of the cores. The distribution of illite nearly resembles the shape of an oxygen isotope curve. The percentage of silt shows highest values during peak warm times. silicoflagellates were found in all surface samples in varying amounts.

\section{STRATIGRAPHY}

Owing to the paucity of biogenic carbonate, cores from south of the Antarctic Polar Front are not included in the construction of the Quaternary isotope chronostratigraphy [Imbrie et al., 1984; Prell et al., 1986; Martinson et al., 1987]. So far, all interpretations of southern high-latitude glacial and interglacial paleoenvironments [i.e., Ledbetter and Ciesielski, 1986; Burckle and Abrams, 1987; Fütterer et al., 1988; Pudsey et al., 1988] suffer from the lack of a detailed stratigraphy due to low levels of carbonate. Even a coring device with a large volume cannot provide sufficient foraminiferal tests to allow any accelerator mass spectrometer (AMS) dating. Since a few years ago, $\delta^{18} \mathrm{O}$ and $\mathrm{S} C$ isotopes can be measured on extremely small samples (20 pg) because of the development of mass spectrometers with an automatic preparation device, which only need three to six tests for one measurement.

The cores discussed in this paper include the first from the Antarctic continental margin in which sufficient foraminiferal tests were found and stable isotopes have been measured. Core PS1388 is from $69^{\circ} \mathrm{S}$ from the slope at a water depth of $2536 \mathrm{~m}$. The stable isotope record was generated from benthic (Epistominella exigua) as well as planktonic species (Neogloboquadrina pachyderma) of two different size fractions (Figure 2). Although this record is somewhat affected by diagenesis, it is complete and is typical of the deep-sea record elsewhere. This is the only record of the Antarctic continental margin, spanning the last $300 \mathrm{kyr}$, which could be correlated in detail with the global isotope stratigraphy [Mackensen et al., 1989].

The Interpretation of the isotopic data in the other cores in most cases remains difficult because of strong diagenetic alterations as shown in Core PS1648 (Figure 4). Low values of 3.6 to $3.7 \%$ for $\delta^{18} \mathrm{O}$ were found in the surface sediments of all cores. In general, values lower than $4 \%$ are only found in the Holocene sequence. Samples with pre-Holocene ages are in the range of 4 to $5 \%$ and do not attain lower values even in those sediments obviously formed during the warmest intervals of isotopic stages 5 or 7 . Diagenetic dissolution within the sedimentary column has altered the isotopic composition of the tests toward higher values by selectively removing the isotopically lighter carbonate [Savin and Douglas, 1973; Berger and Killingley, 1977; Wu et al., 1990]. Differential dissolution occurs probably as a result of a very low carbonate content of the sediment. Masking of the original isotope signal, as discussed in detail by Grobe et $a l$. [1990b], was most intense during times of high productivity, when most of the carbonate was dissolved on the seafloor because of its deposition at or below the lysocline or even in the range of the CCD. 

(gravel/10cm3)

$0010 \quad 2030 \quad 40 \quad 50 \quad 60 \quad 7080 \quad 90100 \quad 4$
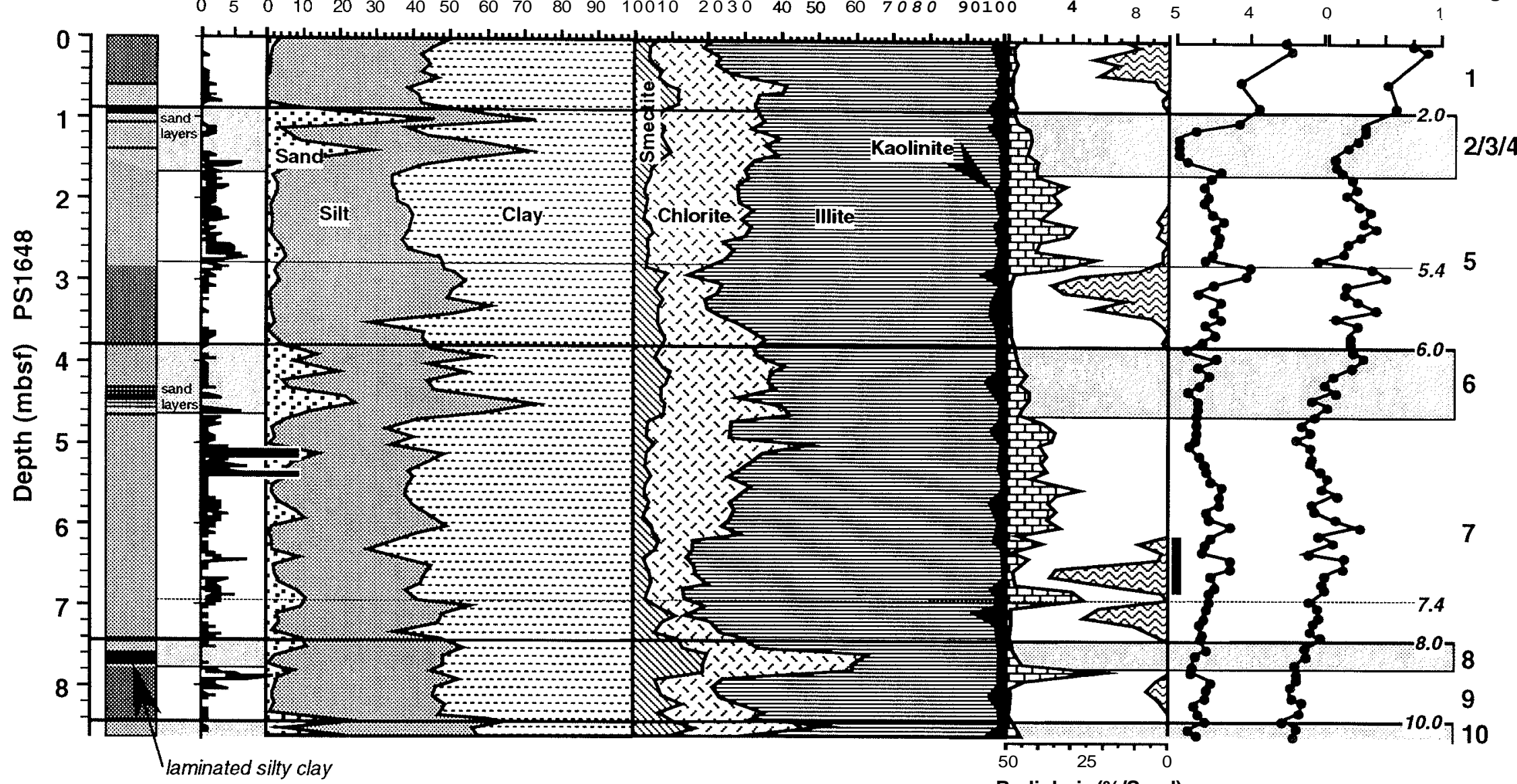

Fig. 4. Sedimentological Parameters of Core PS1648 from the middle of the midslope bench off Atka Iceport. The core at its base is 340 kyr old, and mean Sedimentation rates are $2.5 \mathrm{~cm} / \mathrm{kyr}$. It shows the typical record of the continental margin sediments during the last two climatic cycles. As in most cores of the Antarctic continental slope, oxygen stable isotope data are only of restricted value because of the strong diagenetic alteration of the foraminiferal tests. Stage boundaries have been defined by correlation of significant lithologic changes with the stable isotope record of Core PS1388 [Mackensen et al., 19891. 
TABLE 2. Age Models for All Cores Including an Undisturbed Pleistocene Sediment Sequence of the Last $350 \mathrm{kyr}$

\begin{tabular}{cccccccccccc}
\hline $\begin{array}{c}\text { Age, } \\
\text { kyr }\end{array}$ & $\begin{array}{c}\text { PS1380, } \\
\mathrm{m}\end{array}$ & $\begin{array}{c}\text { PS1388, } \\
\mathrm{m}\end{array}$ & $\begin{array}{c}\text { PS1389, } \\
\mathrm{m}\end{array}$ & $\begin{array}{c}\text { PS1390, } \\
\mathrm{m}\end{array}$ & $\begin{array}{c}\text { PS1394, } \\
\mathrm{m}\end{array}$ & $\begin{array}{c}\text { PS1431, } \\
\mathrm{m}\end{array}$ & $\begin{array}{c}\text { PS1479, } \\
\mathrm{m}\end{array}$ & $\begin{array}{c}\text { PS1481, } \\
\mathrm{m}\end{array}$ & $\begin{array}{c}\text { PS1591, } \\
\mathrm{m}\end{array}$ & $\begin{array}{c}\text { PS1640, } \\
\mathrm{m}\end{array}$ & $\begin{array}{c}\text { PS1648, } \\
\mathrm{m}\end{array}$ \\
\hline 12.05 & 0.95 & 0.60 & 0.70 & 0.60 & 3.20 & 1.30 & 0.40 & 0.20 & 0.50 & 0.80 & 1.00 \\
73.91 & 1.40 & 1.25 & 1.00 & 0.95 & 5.30 & 2.05 & 0.80 & 0.40 & 0.70 & 1.70 & 1.70 \\
110.79 & 1.90 & 1.90 & 2.90 & 1.80 & 6.40 & 3.20 & 1.15 & 0.70 & 1.20 & 2.50 & 2.60 \\
129.84 & 3.00 & 2.90 & 3.70 & 2.70 & & 4.70 & 1.50 & 1.10 & 1.75 & 3.80 & 3.90 \\
180.00 & 3.30 & 3.50 & 4.10 & 3.20 & & 5.60 & 1.75 & 1.30 & 2.00 & 4.80 & 4.60 \\
205.00 & 4.20 & 4.45 & 5.80 & 4.20 & & 7.10 & 2.20 & 1.70 & 2.40 & 5.70 & 5.80 \\
224.89 & 5.20 & 5.10 & 6.40 & 5.10 & & 8.10 & 2.70 & 2.10 & 2.80 & 6.80 & 6.80 \\
244.18 & 6.20 & 5.80 & 7.10 & 5.90 & & 9.40 & 3.10 & 2.40 & 3.30 & 7.80 & 7.50 \\
282.00 & 6.40 & 6.00 & 7.30 & 6.20 & & & 3.20 & 2.55 & 3.45 & 8.30 & 7.75 \\
339.00 & 7.40 & 6.60 & 8.10 & 6.80 & & & 3.55 & 3.20 & 3.90 & 9.40 & 0 \\
362.00 & 7.60 & 6.80 & 8.30 & 7.00 & & & 3.60 & & 4.00 & 9.70 & \\
\hline
\end{tabular}

Ages are from Imbrie et al. [1984] and Martinson et al. [1987].

Because of these severe problems with most of the isotopic data, we developed a lithostratigraphy as a tool for correlating the late Pleistocene sediments. The comparison of the isotopic record of Core PS1388 with the lithological parameters and biogeneous components (Figures 2 and 3) has shown that significant changes occur at distinct times of global climatic change. Those prominent lithologic changes were correlated with the isotopic events of the stable isotopic record of Core PS1388 (Figure 2). The changes were Sound to be similar in all late Pleistocene sediments around the Weddell Sea between the Antarctic Peninsula and $35^{\circ} \mathrm{E}$ [Brehme, 1991; Melles, 1991; Fiitterer, 19911. Variations of the biogenic constituents can be correlated between cores and are synchronous within their resolution. A Surther improvement of the lithostratigraphy was made feasible using the lithologic variations of the terrigenous detritus. Clay mineral composition and grain size parameters are influenced by local conditions and sources but show significant distribution patterns which could also be correlated in detail between cores (Figure 3).

\section{Age Models}

To compute age models for the last $300 \mathrm{kyr}$, stratigraphic fixed points were defined where specific lithologic changes can be correlated with distinct events of the isotope chronostratigraphy. The correlation of the sedimentological Parameters between cores and the correlation of lithologic changes with the isotopic events of Core PS1388 (Figure 2) provide a sufficient data base to calculate sedimentation rates and, finally, to stack the most important parameters. The age models assume both zero age for core tops containing a well-defined Holocene section and constant sedimentation rates between isotopic events. Stratigraphic fix points (Table 2) up to event 8.0 were derived from the compiled chronostratigraphy of Martinson et al. [1987]; Surther stratigraphic calculations were based on the SPECMAP data set [Imbrie et al., 1984] with stage boundaries as defined by Prell et al. [1986]. Sedimentation rates across stages 2 to 4 and events 5.1 to 5.4 in all cores were integrated, because in this case stage boundaries could not be determined by lithologic changes.

Isotopic events at the glacial terminations (2.0, 6.0, 8.0, and 10.0) can easily be defined by significant lithologic changes and were placed at a depth where decreasing carbonate content correlates with the first occurrence of silica, indicating a drastic increase in productivity with the onset of the interglacial. The lithology of event 5.5 consists of an opal peak followed by relatively high carbonate values in the uppermost part of this horizon. Opal decreases to zero values toward event 5.4, which was placed at the top of the first carbonate occurrence within stage 5. Other lithologic changes, such as an increase in clay content and a significant minimum in the warm time illite peak, are in correspondence and support the definition of event 5.4 (e.g., PS1648, Figure 4).

To solve problems with sedimentation rates around isotopic event 7.1, insolation, as calculated by Berger [1978], was taken into account (Figure 5). Sedimentation rates during event 7.1 were too high when using the correspondence of lithologic changes, in particular, the decrease in carbonate content, with stage boundary $6 / 7$. Instead, this lithologic change was correlated with the decline in Insolation during the southern summer at $70^{\circ} \mathrm{S}$ around $180 \mathrm{kyr}$, shifting the age for the lithologic change around event 7.0 to about $10 \mathrm{kyr}$ later (Figure $5 \mathrm{a}$ ). Calculations of the influence of orbitally induced insolation changes on Antarctic sea ice cover suggest influence on Pleistocene sea ice distribution [Crowley and Parkinson, 19881. Less sea ice might have affected sedimentation processes by extending interglacial conditions, especially surface water productivity, into the beginning of glacial stage 6 .

One Surther stratigraphic fixed point, not available 


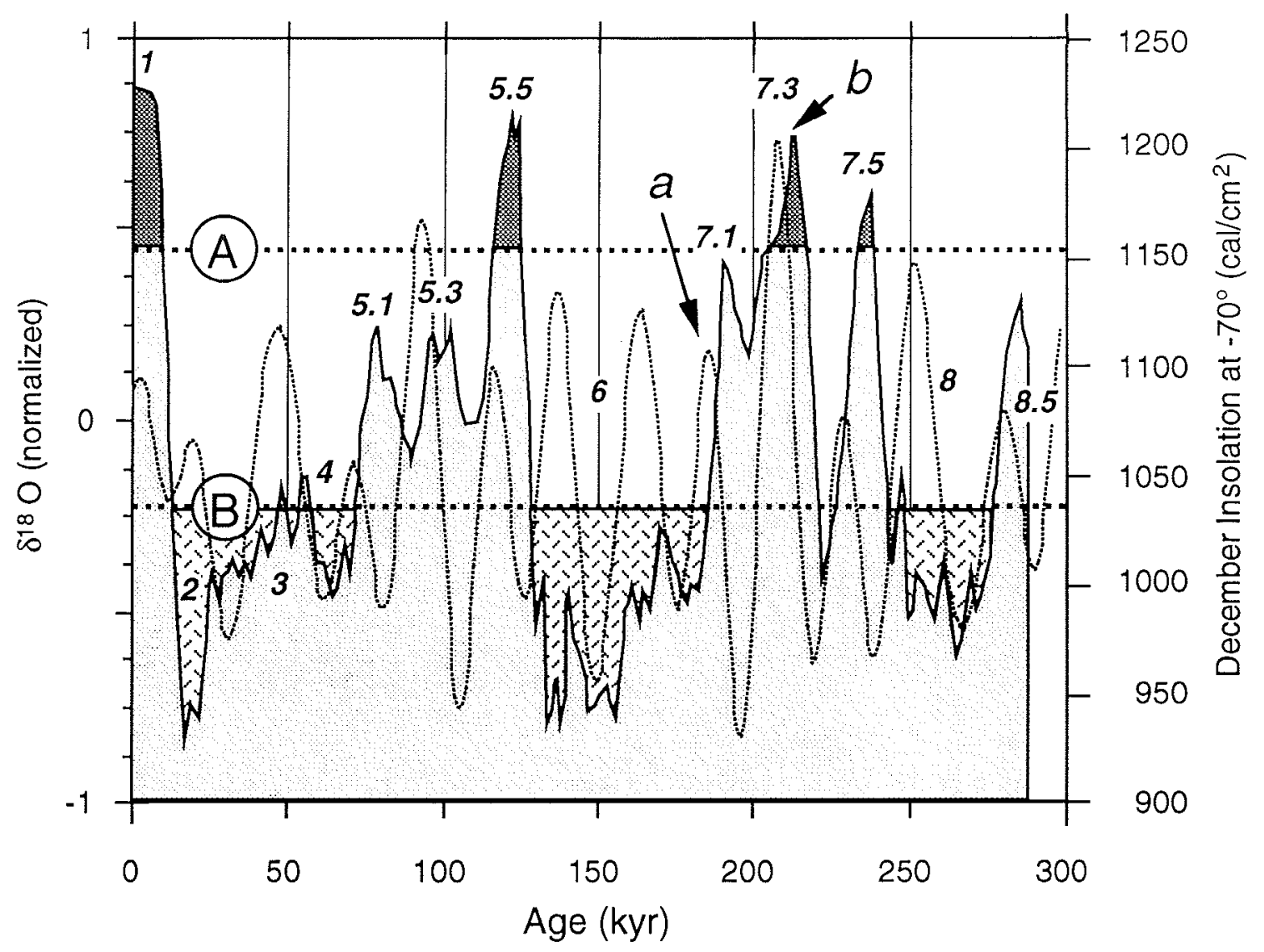

Fig. 5. Summer insolation [Berger, 1978] in the investigation area plotted together with the oxygen isotope stratigraphy of Martinson et al. [1987]. Slight differences between global climate and the sedimentary record, as found in this study, can probably be explained by local summer insolation. During distinct sensitive times $(\mathrm{a}, b)$ of global climatic change, the local insolation influences sea ice conditions and thus primary productivity. Levels A and B indicate climatic thresholds at which sediment composition drastically changes.

from the standard chronostratigraphy, was defined at $205 \mathrm{kyr}$ representing the "shoulder" between event 7.2 and event 7.3 (Figure Sb). This boundary was placed by Interpolation at one of the significant changes in productivity, defined by a change from silica to carbonate microfossil preservation. In addition, this change correlates with a typical decrease in illite content within the drastic change of the clay mineral association between event 7.3 and event 7.2. Both lithologic changes were found to be significant in all cores (Figure 7; see arrows).

Event 7.4 was defined at a carbonate peak within stage 7 (Figures 2 and 3). This is the only occurrence of carbonate which cannot be correlated to a lithological change in clay mineralogy or grain size within the full sedimentary record of the last $300 \mathrm{kyr}$. It is obvious that the short duration of the cold event 7.4 has had an effect only on the sea-ice-controlled productivity, not on the continental-ice-controlled processes of terrigenous sedimentation.

The section between $205 \mathrm{kyr}$ and event 7.4, in the curve of Martinson et al. [1987], marked by the pronounced warm event 7.3, was found to be composed of two peaks in silica content in most of the cores with sufficient resolution (e.g., Figure 4, Core PS1648, bold line; Figure 3, Core PS1388, 4.4-5.0 m). The double peak is indicative of two events of high productivity. There might be two reasons for the discrepancy with the global chronostratigraphy: (1) the resolution of the stacked isotope record of Martinson et al. [1987] might not be sufficient in this range, or (2) this is a local effect, produced by the superimposition of local insolation and global climate. The peak value of insolation in the investigation area $\left(70^{\circ} \mathrm{S}\right)$ is somewhat shifted by $7 \mathrm{kyr}$ in relation to the chronostratigraphic peak value (Figure $\mathrm{Sb}$ ), which is a further indication that productivity is 


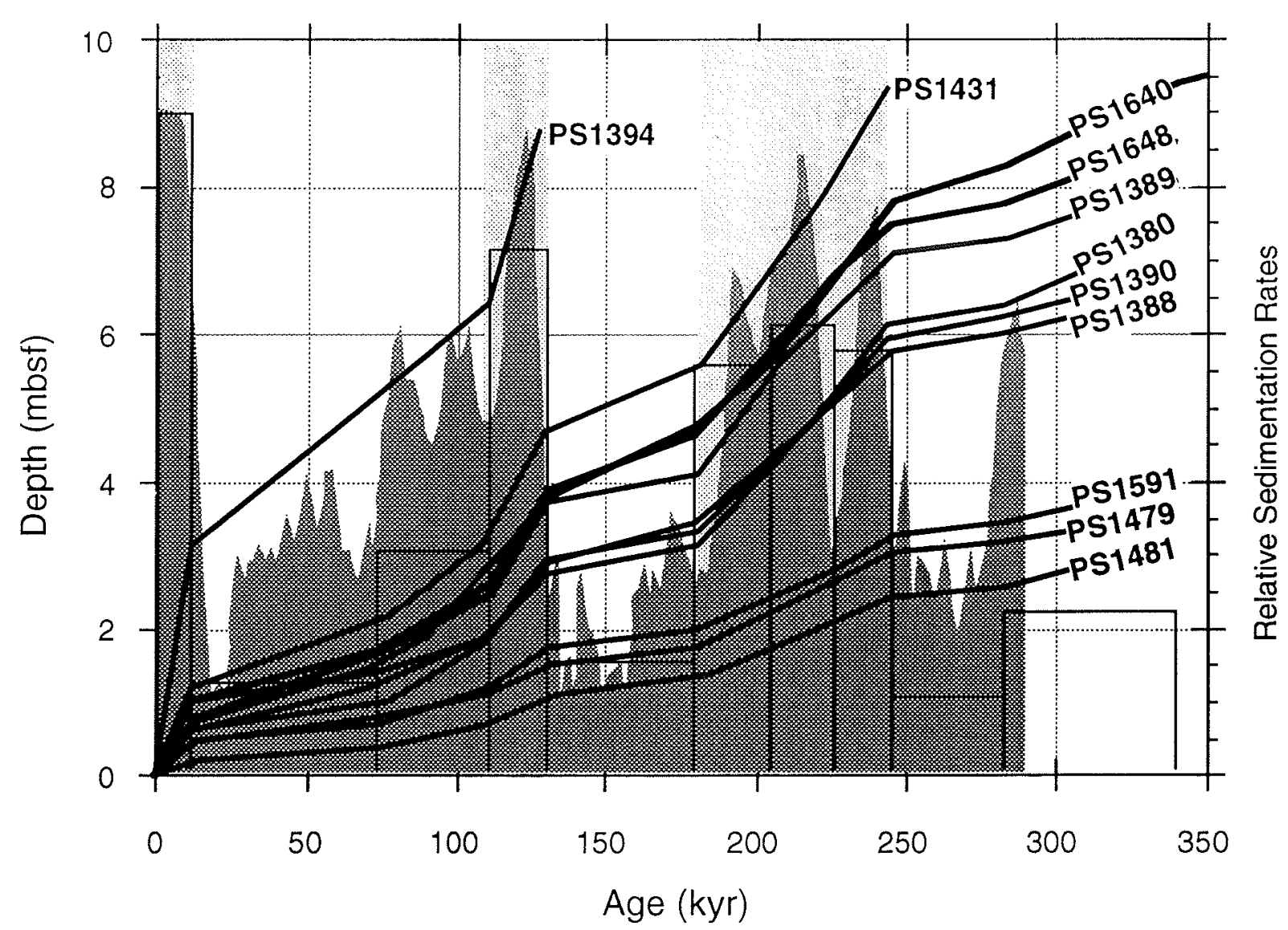

Fig. 6. Age versus depth plot showing sedirnentation rates of all cores in correlation with the oxygen isotope stratigraphy of Martinson et al. [1987]. Highest sedirnentation rates are found close to the continent in Core PS1394. Generally, sedirnentation rates decrease with distance from the shelf and in the vicinity of the Wegener Canyon. The histogram plotted as an underlay shows relative sedimentation rates calculated from the stacked record of all cores, indicating 3 to 4 times higher values during interglacial compared with glacial periods.

controlled by an interaction of global climate and local insolation changes in the high-latitude Antarctic Ocean.

\section{Sedimentation Rates}

Integrated sedimentation rates (Table 1, Figure 6) were calculated for distinct glacial and interglacial periods. Sedimentation rates in general decrease with distance from the continent and within a climatic cycle from interglacial to glacial. Rates are highest very close to the continent owing to the higher input of terrigenous material (Core PS1394). Low sedirnentation rates were Sound in the vicinity of the Wegener Canyon (cores PS1591, PS1479, and PS1481).

Sedimentation rates during the last $300 \mathrm{kyr}$, presented as a relative data stack (Figure 6, histogram), indicate that peak warm episodes, including isotopic stages/ events $1,5.5$, and 7 , are 4 to 5 times higher in comparison with glacials integrated over all sites. Because rates are calculated as mean values between stratigraphic fix points, it is difficult to determine detailed sedimentation rates within an individual climatic event, although the Holocene exhibits the highest values compared with other warm events. Within a climatic cycle the Holocene mainly reflects sedimentary conditions at the very beginning of an interglacial up to the climatic optimum. This indicates that sedimentation rates are highest during the terminations and the first few thousand years of an interglacial. The rates then decrease following the climatic optimum. This produces a sawtooth pattern of the sedimentation rate during peak warm intervals when a warm climatic event rapidly follows a glacial maximum.

The sedimentation rates during stage 9 are low in comparison with later stages, because rates are integrated for the full stage. In this case, event 8.5 was defined as belonging to interglacial stage 9 . In addition, 
sequences deeper than about $5 \mathrm{~m}$ below the surface are increasingly compressed by the gravity coring procedure [Melles, 19911; thus the apparent reduction of sedimentation rates is most probably artificial.

\section{STACKED SEDIMENTOLOGICAL RECORD}

A composite record was established for the interpretation of the continental margin sediments by stacking the specific sedimentological parameters. Detailed analysis of 11 cores (Figures 3 and 4), including the last two climatic cycles, permits the use of a method which is new in this context. Stratigraphic fixed points, as defined above, were used to compute an age model for each of the cores. After calculating the age of every individual sample, each parameter was calculated in equidistant time steps for the last $300 \mathrm{kyr}$ to allow stacking of parameters between cores. Each data set was normalized to values between 0 and 1 by division by the maximum value. Individual data for each time step and each parameter on all cores were added and divided by the number of cores. Plots of four selected parameters (carbonate, radiolaria, illite, silt) versus time show a good correlation between all cores (Figure 7). Strongest variations between cores occur in the terrigenous parameters during glacials. Relative changes of clay mineral composition and grain size are mainly controlled by the glaciological processes on the shelf and are therefore dependent on the distance of the core location from the shelf break.

The stacked sedimentological records were plotted versus time together with the standard chronostratigraphic curve of Martinson et al. [1987]. The records show the relative changes of each parameter and represent mean values of slope sediment composition (Figure 8). Individual signals will be enhanced toward the shelf; others will be masked at the deeper slope. Thus interpretation of the stacked record will provide more general Information about sedimentation processes at the slope. Some variations are representative at least for the margin of the eastern Weddell Sea and some for most of the Antarctic coastline of the Atlantic part of the Southern Ocean.

\section{Opal}

The percentage of radiolarians in the sand fraction was determined by coarse fraction analysis. Investigations of smear slides have shown that the occurrence of radiolarians can be correlated in detail with the siliceous microfossil content in the silt fraction such as diatoms and silicoflagellates [Grobe and Kuhn, 1987]. Thus the quantity of radiolaria could be used to predict the occurrence of silica in the sediments, because this parameter can easily be assessed and radiolaria are more resistant against solution.

The siliceous microfossils, as indicated by the radio- larian peaks, are typically concentrated in distinct horizons which were found to occur in all cores (Figures 2 and 3). Siliceous microfossils occur at the glacial terminations and reach peak values close to the interglacial climate optimum. Opal decreases to zero again when the climatic curve drops below a distinct threshold (Figure $5 a$ ). In cores which included the full Pleistocene sedimentological record, silica was found only during the last five interglacial stages (Figure 3, e.g., cores PS1388, PS1479, and PS1591). The sole exception was found in Core PS 1481, where high silica values below $7.50 \mathrm{~m}$ are due to the Pliocene age of the lower section of this core [Grobe et al., 1990a].

\section{Carbonate}

Calcium carbonate content is mainly derived from the planktonic foraminifera Neogloboquadrina pachyderma (sinistral), some benthic foraminifera, and very few coccoliths and ostracods. N. pachyderma is a permanent component of Antarctic sea ice which may contain up to 1000 individuals per liter of melted ice [Dieckmann et al., 1991]. Carbonate percent can generally mimic the oxygen isotope curve, which means that it reflects paleoclimatic history. However, the amount of carbonate preserved in the sediment can be influenced by dissolution. Carbonate values decrease to almost zero in sediments rich in silica (Figures 3 and 4). During peak warm times, both opal and carbonate are produced in surface waters, but because of high organic matter fluxes, calcareous shells are not preserved. We explain the lag of decreasing carbonate relative to the oxygen isotope curve at stage boundary 7/6 (Figure 8) with an Insolation maximum which might have temporally extended interglacial sea ice conditions (Figure $5 a$ )

\section{Ice-Rafted Debris}

Close to the continent, ice-rafted debris (IRD) is one of the most important parameters indicating the response of the Antarctic ice sheet to climatic change. The highest occurrence of IRD is found during interglacial stages. During warm episodes, the increasing IRD content shows a time lag relative to the terminations of up to several thousands of years (Figure 8). During stage 7 , IRD increases at event 7.4, and in stage 5 IRD increases at event 5.4; these are the highest amounts of IRD found within the Holocene. Stage 7 shows higher values than stage 5 in almost all cores investigated. Coarse and medium sand follows the distribution of gravel.

\section{Grain Size}

The sediments are glaciomarine and thus consist of sandy mud with varying amount of gravel and rocks. Most information on transport mechanisms, such as current activity and ice rafting, can be derived from the silt/clay ratio and from the grain size distribution of the 


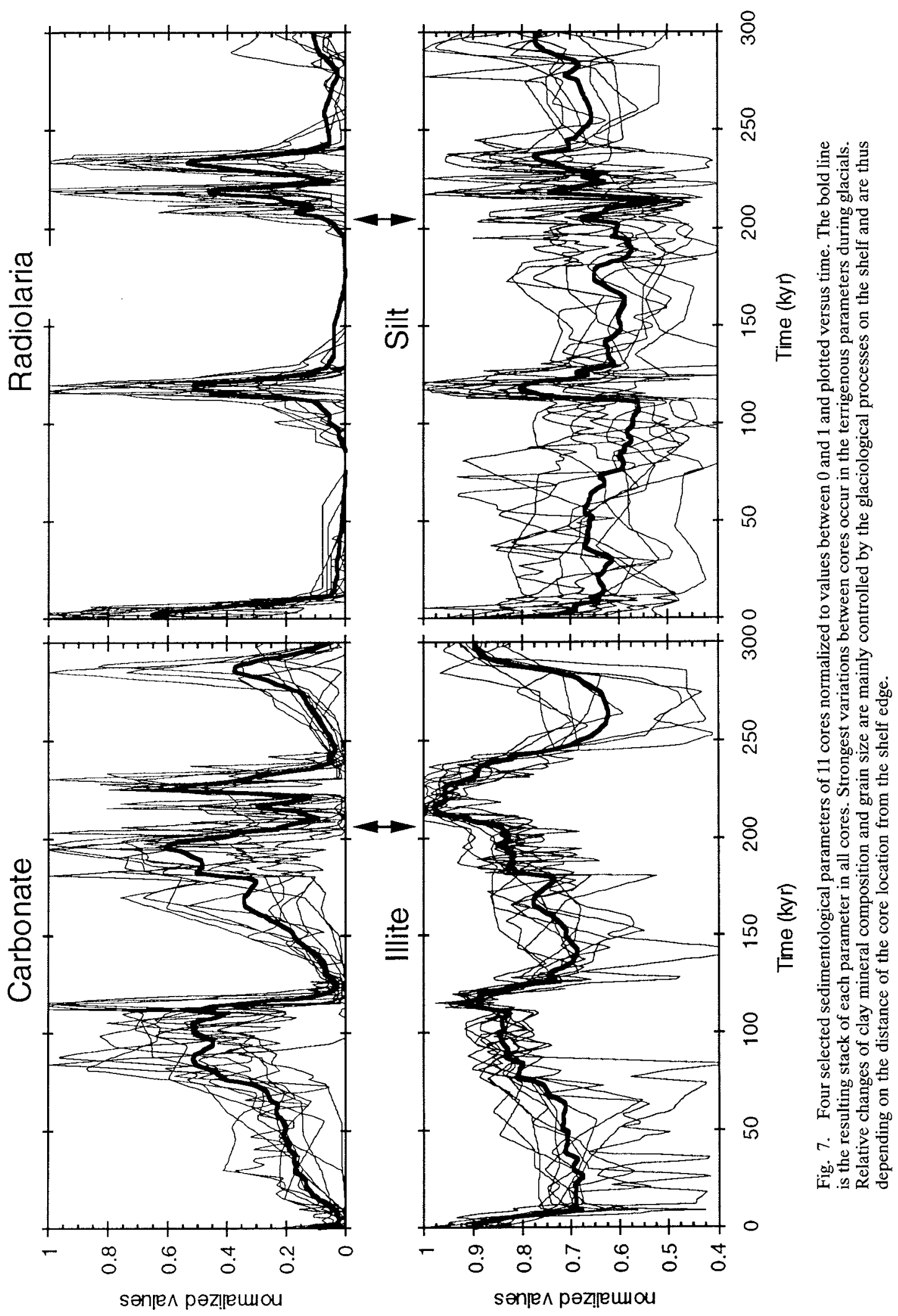


THE ANTARCTIC PALEOENVIRONMENT

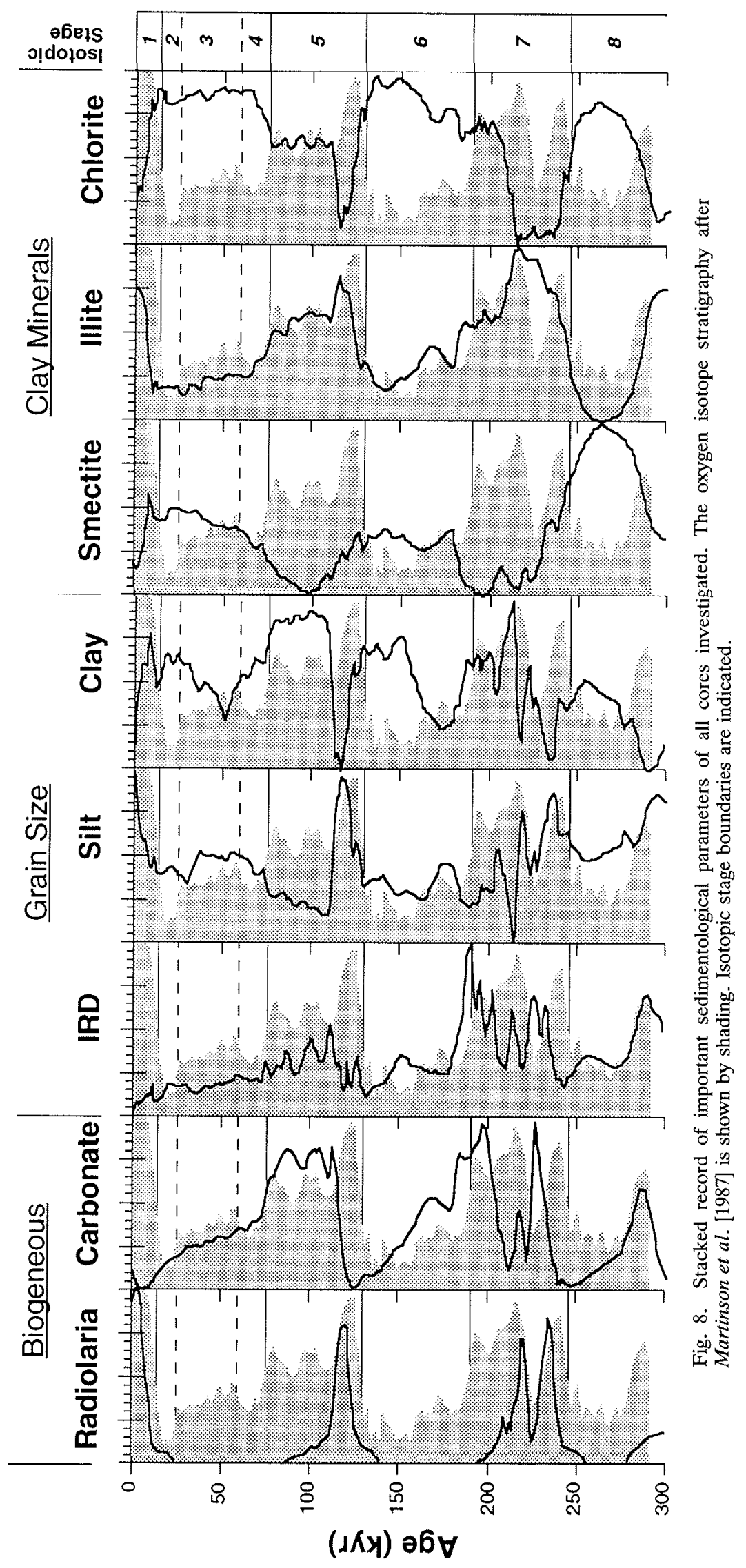


silt fraction (2-63 pm). Diatom frustules, which were found exclusively during peak warm events, are a minor part of the silt fraction and are not important to the grain size distribution. The amount of terrigenous silt has maxima during the warmest climatic events, although a time lag of about $5 \mathrm{kyr}$ between glacial termination and changing grain size values can be observed (Figure 8). Within the transition from glacial to interglacial conditions, the rnean of the silt fraction changes from 7.4 to 6.6 phi. The corresponding change in skewness of the bulk sediment from 0 to -0.2 is due to a decrease in the amount of clay. Both parameters indicate changes in the fine tails of the grain size distributions toward coarser sedirnents when the ratio of current-derived to icerafted material changes in favor of the latter.

\section{Clay Minerals}

Close to the continent, the clay mineral associations are sensitive indicators of ice rafting and of the extent of ice coverage. In particular, smectite, which is carried long distances by currents, can be considered to be the "marine sediment noise." A high content of srnectite was found in the clay fraction deposited during times of maximal ice expansion (Figure 8). With the termination of the glacial, the smectite content does not show a sudden change due to a lagged and slowly increasing dilution by ice-rafted illite (Figures 3 and 8). Smectite reaches minimum values during the midpoint of the following interglacial. Chlorite increases with the end of an interglacial and reaches peak values during glacial maxima, indicating an enhanced input of shelf sediments.

The peak value of smectite during glacial stage 8 (Figures 4 and 8 ) is a local effect, produced by a setting when the adjacent ice shelf and/or closed sea ice conditions cover the slope area for a distinct time span. Current-transported clays and some downslope sediment movement produce a clay association, consisting of smectite and minor chlorite. Ice rafting and biological productivity are insignificant contributors to this sedimentary process.

\section{CLASSIFICATION OF SEDIMENT FACIES}

Correlation between the different sedimentological parameters allows the identification of five different sedirnent facies. The facies can be related to different sedimentary environments which are controlled by the slope morphology and by global and local clirnatic changes. The most important parameters used for the classification are grain size distribution, including the gravel fraction as an indicator of ice-rafting activity, the association of clay minerals (chlorite, illite, and the smectite group), siliceous microfossil and carbonate content, and finally the sediment textures as observed in the X-rayed core slices.

\section{Holocene Shelf Fades}

During the late Holocene, on the continental shelf a sedirnent facies is deposited that includes overconsolidated diamictons and residual glacial-marine sedirnents. The water depth at the present-day ice shelf edge varies between 200 and $400 \mathrm{~m}$ depending on the locations of ice rises and capes. The mean depth of the overdeepened shelf is around $300 \mathrm{~m}$. From the investigation of long piston cores it is known that basal tills appear to be most widespread on the Antarctic continental shelf. They are overlain by glacial-marine sedirnents in most areas [Andersonet al., 1980, 1991]. Owing to the high content of gravel (up to $30 \%$ ), it was not possible to recover the basal till in the investigation area, and thus in this paper only the uppermost sequence of the Holocene sedimentary record was analyzed. Despite this lack, the composition of the Holocene shelf sedirnents is crucial for the reconstruction of sediment transport processes at the continental margin.

The short cores of up to 0.6-m length show that the acoustically reflective sedirnent is a mostly unfossiliferous, apparently overconsolidated diamicton. In rnany places the surface of the shelf is modified by iceberg scour. The diamicton is deposited by melting processes beneath the ice shelf, most probably close to the grounding line, and is defined as a transitional glacialmarine sediment [Anderson et al., 1980]. Fine fractions of the grain size distributions are subsequently winnowed by currents, producing a residual glacial-marine sediment (Anderson et al. [1980]; Figure 9, Holocene shelf facies). The settling fines $(<30 \mu \mathrm{m})$ are entrained by the Antarctic Coastal Current, which has velocities of up to $17 \mathrm{~cm} / \mathrm{s}$ [Carmack and Foster, 1975]. Parts of the fine sediments are transported off the shelf, where they contribute to the grain size distribution of the slope sediments forming a compound glaciomarine sedirnent (e.g., carbonate facies, Figure 9). A portion may be transported further with the Weddell Gyre to the SE to the Filchner Trough, where thick laminated clays were found [Melles, 1991].

In addition, the mineralogical composition of the clay fraction remaining on the shelf is indicative of a residual glaciomarine sediment (Figure 10). The weight percentage of chlorite is about twice as high there as on the slope and the abyssal plain. All terrigenous material deposited on the shelf is directly delivered from Queen Maud Land by the continental ice. The geology of the coastal areas of the eastern Weddell Sea was reconstructed from dropstones, dredged on the shelf [Oskier$s k i, 1988$ ] and from pebbles and sands in tills [Andrews, 1984; Anderson et al., 1991]. Close to the investigated area the classification in different petrographical provinces shows mainly Mesozoic, in most cases Jurassic, basalts with different degrees of alteration [Rex, 1967; Juckes, 1972; Peters, 1989]. The source of chlorite may 

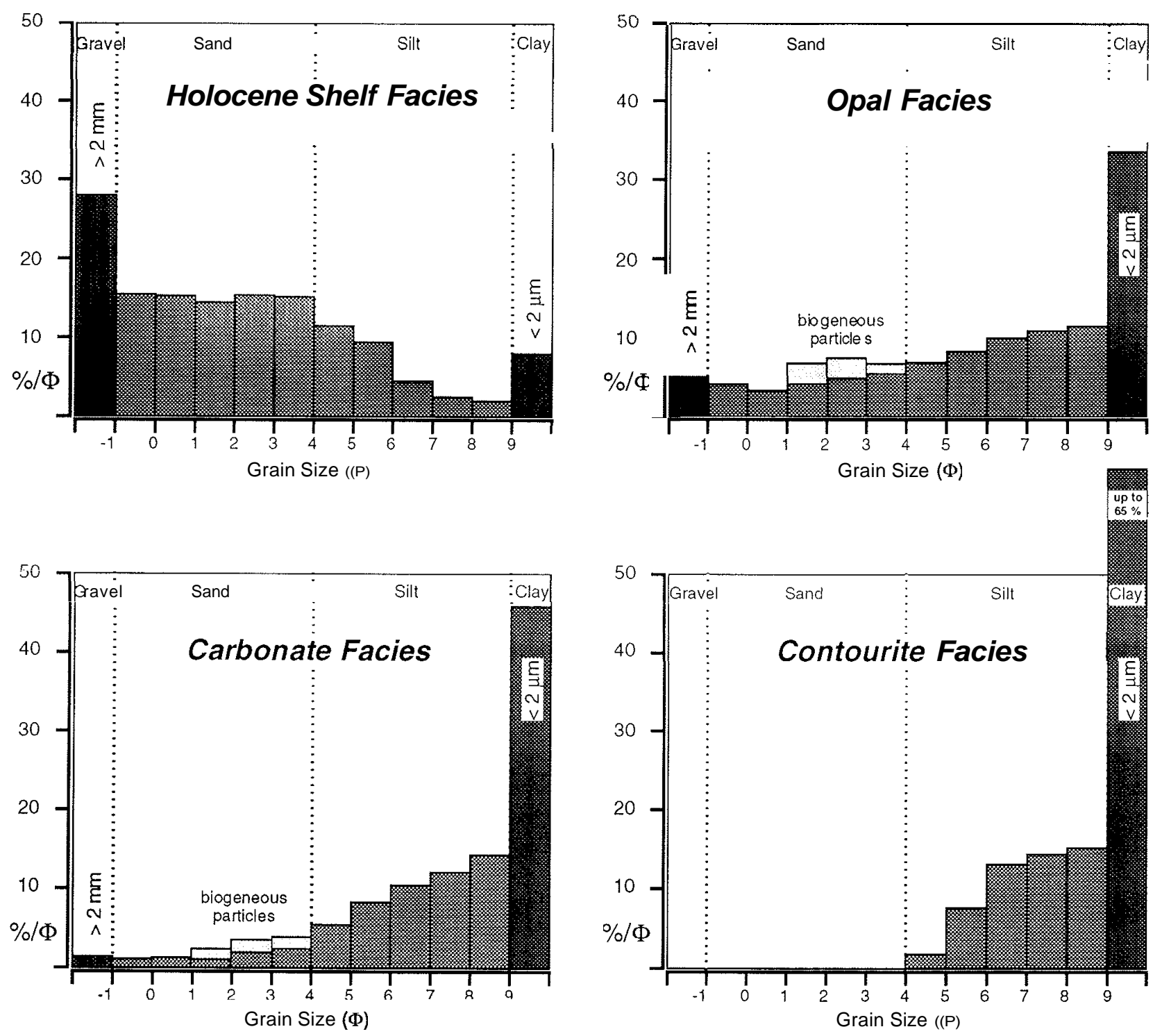

Fig. 9. Typical grain size distributions of four different sedimentological facies. In the Holocene shelf facies the fine fractions are partly winnowed by the Antarctic Coastal Current. The opal facies is deposited on the slope during peak warm times. The carbonate facies can be found during moderate interglacial to glacial conditions, whereas the contourite facies only occurs during times of closed sea ice conditions, presumably during further advances of the ice shelves. In all slope facies, the fine fractions, missing on the shelf, are added to the ice-rafted component, depending on the contribution of the two transport processes, ice rafting and current transport.

thus be the basic to ultrabasic rocks, where weathered olivine and pyroxene have formed chlorite.

Determination of sedimentation rates of the shelf sediments is difficult and was done only at one site (Core 206, 420 m, Norwegian Antarctic Research Expedition 197811979 [Elverh $\phi i$ and Roaldset, 19831) where sufficient carbonate was found to use ${ }^{14} \mathrm{C}$ analysis. The analysis of a coral gave a rate of about $3 \mathrm{~cm} / \mathrm{kyr}$. However, it is evident that sedimentation rates will vary greatly along the ice edge in correspondence with the morphological features of the shelf and the ice shelf and the intensity of the ACC. On the shelf, it remains problematic in getting long-term information about the behavior of the Antarctic ice sheet because it is difficult to penetrate the pebbly sediment with a gravity coring device and to produce any stratigraphy. Though piston cores up to $10 \mathrm{~m}$ in length have been taken on the Ross Sea and Weddell Sea shelf, they suffer from the lack of 


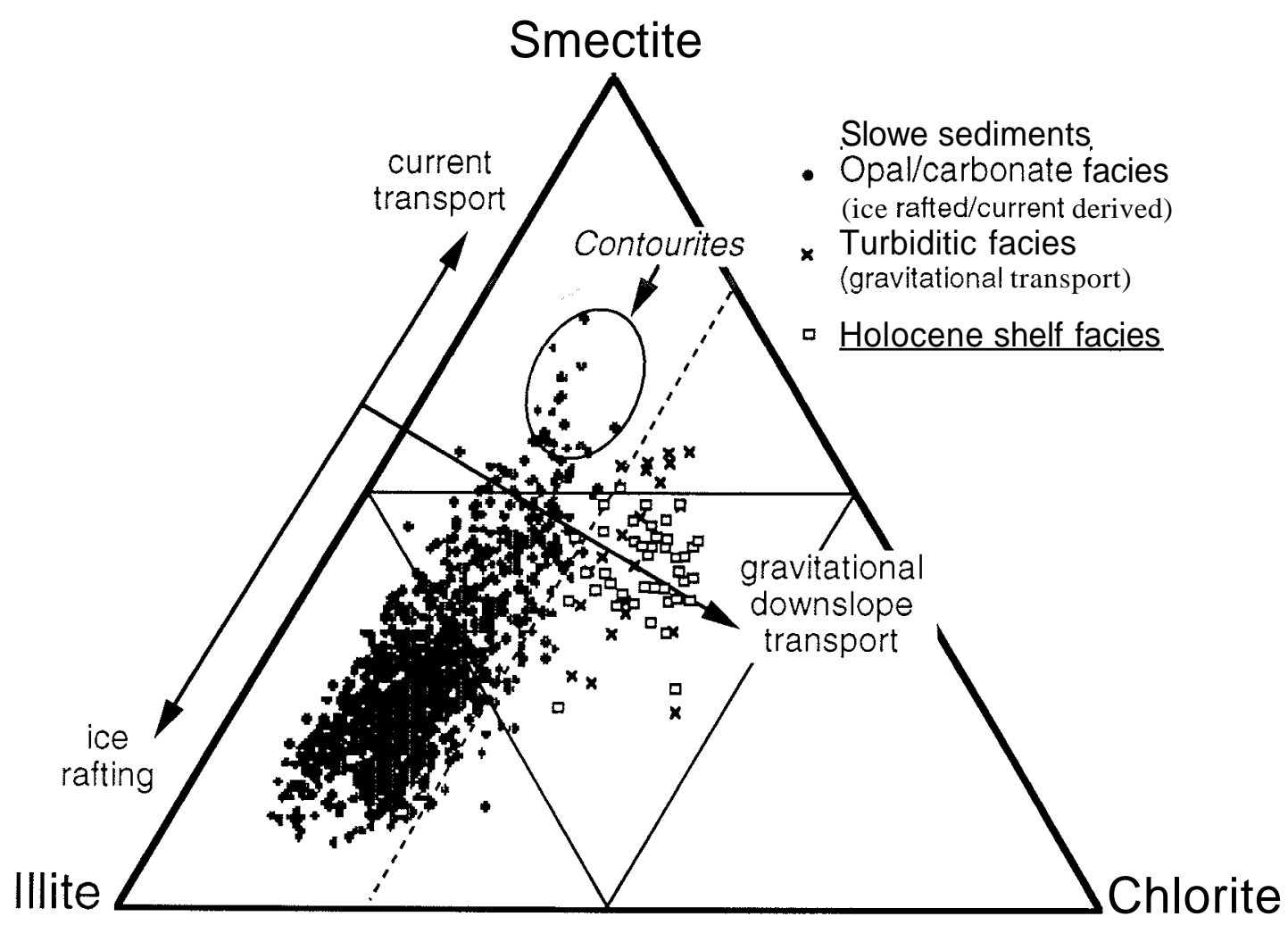

Fig. 10. Ternary diagram of clay mineral assemblages. Included are 1265 analyses of slope sediments and 51 samples of the shelf deposits. The slope sediments plotted on the left-hand side of the dashed line consist mainly of illite and smectite. Their quantitative relation is controlled by the ratio of current transport to ice rafting. The contourite facies, deposited only by current transport, shows highest smectite values. On the contrary, sediments deposited during peak warm times and intense ice rafting are dragged more toward the illite corner. Typical of the shelf sediments is a higher content of chlorite. Such assemblages with a high chlorite content are found on the slope only in the turbiditic facies. The turbiditicfacies represents small proximal turbidites, triggered and fed from the shelf by the advancing ice edge.

any stratigraphic information, and investigations are concentrating on a detailed description of the different sediment facies [Anderson et al., 19801. The only Cenozoic long-term sequences, recovered on the Antarctic shelf, were drilled in McMurdo Sound (MSSTS, CIROS, DVDP [see Hambrey and Barren, 1992]), during Deep Sea Drilling Project Leg 28 on the Ross Sea shelf [Hayes et al., 1975] and during ODP Leg 119 in Prydz Bay [Hambrey et al., 1991].

\section{Opal Fades (Peak Warm Interglacial Sediments)}

The opal facies contains a significant number of siliceous skeletons such as diatoms, radiolarians, and some sponge spicules. Sediments of this facies can clearly be separated from other sediment types by its biogeneous content (Figures 8 and 9). The facies is almost barren of carbonate, with the exception of very few planktonic foraminifera. In places, these were just sufficient for one single stable isotope analysis. The sediment includes occasional dropstones. Intense bioturbation masks all primary sediment structures. Arenaceous benthic foraminifera occur together with the opal facies but were found only in surface sediments [Mackensen et al., 1990]. The tests are diagenetically destroyed at larger sediment depth.

In the investigated area the uppermost surface layer of the sediments between 300 and $10 \mathrm{~cm}$, depending on the sedimentation rate, is rich in siliceous hard parts. This facies represents the Holocene deposits and is also typical for the modern sedimentary environment. Correlation of the opal facies between cores is supported by the $\delta^{18} \mathrm{O}$ data, which are unaltered in the Holocene sequence, presenting a well-defined stage 1 .

The opal facies was found only in five horizons which correspond to the peak warm events of the last interglacial stages $1,5,7,9$, and 11 . This is probably because 
during the last $425 \mathrm{kyr}$, the glacial/interglacial climatic amplitudes [Ruddiman et al., 1989] were higher than in earlier times and climatic optima provided totally icefree conditions in the summer months and thus higher biogeneous silica fluxes. We assume that the variations in opal content are the result of varying siliceous primary productivity rather than a result of changes in deep-sea opal dissolution. This is in agreement with the findings of Mortlock et al. [1991], from sites further north close to the Polar Frontal Zone.

The clay mineral composition is characterized by peak values of illite, which can be attributed to transport mechanisms, e.g., ice rafting (Figure 10). Grain size distributions with a low clay content, a silt distribution with peak values in the range of coarse to medium silt, and increasing values of IRD (gravel and sand) toward the top are typical of the opal facies. The minimum clay and fine silt values are due to less deposition resulting from increased current activities (Figures 8 and 9).

A further important process is the impoverishment of the fine fraction by enhanced bioturbation. In most marine environments, bioturbation is sufficiently active to modify the deposited sediments as a result of various biological activities. One of the most important effects of the organisms is remixing of the beds so that particles are continuously resuspended and can be entrained by currents. Experiments with poorly sorted sediments, similar to glaciomarine deposits, have shown that grain size distribution, particularly in the fine tail range, is a reflection of the efficiency with which the bed was mixed [Singerand Anderson, 1984].

\section{Carbonate Facies (Moderate Interglacial to Glacial Sediments)}

During visual core description of most of the cores, cyclic lithologic changes were observed. The different sediment colors varied between light olive gray and brownish gray. Typical features of this facies are a light olive gray sediment color (5Y5/2, Rock Color Chart) and a significant amount of carbonate. Carbonate content is controlled by a single species of planktonic foraminifera (Neogloboquadrina pachyderma) which was up to $98 \%$ left coiling. The carbonate content may reach up to $25 \%$ and depends directly on the distance from the continent because of the extent of dilution by terrigenous material. Benthic calcareous foraminifera and very few coccoliths and ostracods may make up $<1 \%$ of the carbonate. Their contribution to the carbonate content is unimportant, but their frequency can be correlated with the number of planktonic foraminifera.

Ice-rafted material, such as dropstones and sand, is common in the carbonate facies. Grain size distribution, as well as clay mineral composition, change by a small extent with climate. The amount of clay and the chlorite content both increase as the climate deteriorates. Bio- turbation is of variable intensity and in most places masks the primary sedimentary structures.

\section{Turbiditic Fades (Ice Advance Deposits)}

The turbiditic facies consist of small proximal turbidites, which are organized in graded layers of gravel, sand, and silt, and only occur on the continental terrace close to the upper steep slope. The sediment is almost barren of biogeneous particles and has a characteristic mineralogical composition which is dominated by chlorite and smectite (Figure 10). The high chlorite/illite ratio, a low content of glauconite, and higher values of rock Fragments and gravel show a relationship to the residual glaciomarine sediments of the shelf. Sediment facies colors, described from different core iocations on the shelf close by (see, e.g., Anderson et al. [1981], Kaharoeddin et al. [1980], and Elverhoi and Roaldset [1983]) correspond well with the typical olive gray color of the turbiditic facies (N3-5Y3/2, Rock Color Chart).

The turbiditic facies is thought to be material from moraines, transported and released by the advancing ice sheet during sea level lowstand. The sediment was sorted during gravitational transport down the upper slope as observed by sediment textural analysis of gravity flow deposits from this area, showing size sorting and transformation of glacial sediments into sorted sand [Wright and Anderson, 1982]. Larger cobbles are deposited close to the shelf/slope transition as can be observed in the sediment echo soundings showing only a hard and very uneven surface reflector. Large dropstones were also abundant in biological dredge hauls in this area [Voss, 1988]. The upper slope is covered with gravel and sand, whereas most of the finer fractions are deposited on the landward side of the slope bench, where the slope gradient decreases. At a greater distance from the source area, on the seaward side of the bench, no distal part of the turbidites was observed. Those sediments may have been caught and transported to the deep sea in branches of canyons, cutting into the upper slope (e.g., Wegener Canyon [Fitterer et al., 1990]).

\section{Contourite Fades}

The contourite facies consists of thin to medium beds containing horizontal laminae of mud and silty clay. No grain sizes coarser than medium silt occur (Figure 9). Descriptions of the grain size distributions of the contourites in this area were first published by Anderson et al. [1979]. The fine sediments originate from the winnowing processes at the upper slope and are, when reaching increasing water depth, transported and deposited by weak bottom currents. It is known from bottom photographs that the bottom currents in the Weddell Sea flow as contour currents parallel to the bathymetric contours of the continental margin, transporting sedi- 
ments to the south, around the Weddell Sea, and finally along the Antarctic Peninsula into the South Atlantic [Hollister and Eider, 19691.

A facies originating from contour currents will mostly be deposited during times of enhanced sea ice conditions when other sedimentation processes, such as ice rafting and gravitational transport, become unimportant. Peak values of smectite are typical of the contourite facies. Smectite increases in all clay fractions when the amount of current-derived material increases (Figure 10). In addition, the missing IRD content suggests deposition under a closed sea ice cover. The laminated structure is the consequence of the lack of any bioturbation. The environment is hostile to burrowers because of a break in primary productivity in surface waters due to limited availability of light below the ice. Contourites were found in all cores taken from less than about 100 $\mathrm{km}$ from the shelf break and can be correlated between cores.

The ice edge reaches the continental shelf break during sea level lowstand. During further advances above the slope, a very dense, sometimes closed, cover of sea ice may have stabilized the ice shelf. Lower temperatures in the Antarctic Ocean waters hampered melting from below the ice shelf. Both processes enCourage further seaward advances of the continental ice, finally in building up ice shelves more than $100 \mathrm{~km}$ broad and floating above the slope. It is obvious that the contourite facies is deposited during such strong ice conditions, but it is difficult to specify the contribution of sea ice and/or an ice shelf. During enhanced glacial conditions the sea ice cover is probably attached to the ice shelf margin for longer time intervals, and thus the sedimentological facies, deposited below, is the same.

\section{PALEOCEANOGRAPHY, PALEOPRODUCTIVITY, AND PALEOGLACIOLOGY}

The Southern Ocean today is a mixing reservoir for incoming North Atlantic Deep Water (NADW) and recirculated water from the Pacific and Indian oceans. The contribution of the NADW to the CDW has changed during the climatic cycles, particularly when production of bottom water in the North Atlantic nearly ceased owing to sea ice coverage [Oppoand Fairbanks, 19871. NADW is largely composed of upper ocean waters and thus in the North Atlantic is the most nutrient-depleted deepwater mass formed in the oceans today. In the South Atlantic it still has high $\delta^{13} \mathrm{C}$ values [Kroopnick, 1985]; therefore up to $50 \%$ of the glacial/ interglacial $\delta^{13} \mathrm{C}$ amplitude in the Southern Ocean is due to changes in the contribution of NADW IOppo et al., 1990]. Together with climate-controlled global changes between carbon reservoirs, changes in NADW input into the Southern Ocean are the most important reasons for the changes in $\delta^{13} \mathrm{C}$ observed in high southern latitude cores (e.g., Core PS1648, Figure 4).
Variations in the relative flux of NADW to the Southern Ocean influence the properties of the CDW and surface water [Corliss, 1982; Charles and Fairbanks, 1990]. Because NADW is a heat source for the Antarctic Ocean waters, it consequently influences the formation of sea ice. The amount of sea ice coverage in turn is crucial to the availability of light in surface waters and hence is a main factor in controlling primary productivity. This is particularly important, because in Southern Ocean surface waters no nutrient limitation occurs between the Polar Front and the Antarctic Divergence [Defelice and Wise, 1981]. Variations in productivity during climatic cycles correspond to the extent of sea ice in a way similar to Recent seasonal processes, in which seasonal changes in sea ice cover control productivity and thus biogenic silica flux. This is inferred from sediment trap studies in the Antarctic Ocean [Dunbar, 1984; Wefer et al., 1990].

The sequences of the opal and carbonate facies indicate that cyclicity of primary production varies in response to the glacial/interglacial changes. The events of higher productivity during peak warm times, indicated by maxima in silica content and intense bioturbation, and the variations of carbonate can be explained in terms of interaction of sea ice coverage, deepwater convection, and water masses. On the eastern Weddell Sea continental margin, the WDW appears to influence the depth range of lysocline and CCD [Anderson, 1975; Mackensen et al., 19901. However, the depth of the CCD depends on the properties of water masses and the productivity in surface waters. A high flux of organic matter increases the $\mathrm{CO}_{2}$ content in the interstitial waters and thus the solution of carbonate. During a climatic cycle the CCD oscillates between $4000 \mathrm{~m}$ and $2000 \mathrm{~m}$. It reaches the lowest water depth during the most intense productivity.

The first investigations in this area had already shown a significant amount of carbonate in the Weddell Sea margin sediments, consisting mainly of planktonic foraminifera [Anderson, 1972]. But the high carbonate content of up to $30 \%$ in Quaternary sediments of the continental margin off Queen Maud Land and carbonate values of up to $80 \%$ on Maud Rise [Cordes, 1990] were presumed to be related to ice-free waters in the Weddell Sea Polynya [Grobe, 1986], which had been observed for several years on satellite microwave images [ $Z$ wally et al., 19831. Furthermore, anomalous diatom abundance at Maud Rise was interpreted as resulting from the absence of sea ice in the polynya, permitting increased photosynthesis [Defelice and Wise, 19811. The apparent cyclical variation in carbonate content was inferred to represent the presence and absence of the polynya through time [Fütterer et al., 19881.

Now there is subsequent evidence from other cores which shows that carbonate is common in Pleistocene sediments along the Antarctic coastline of the Weddell $\mathrm{Sea}$, at least between $50^{\circ} \mathrm{W}$ and $40^{\circ} \mathrm{E}$. Pleistocene sedi- 
ments, rich in foraminiferal carbonate, were found on the shelf of the South Orkney microcontinent [Brehme, 1991], on a seamount within the Weddell Sea [Kuhn et al., 1992], and on Astrid and Gunnerus ridges [Fütterer, 1991] in water depths of $<4000 \mathrm{~m}$ (Figure 1). This observation was also made on ODP Leg 113 drill sites [Barkeret al., 1990], and therefore the hypothesis of the influence of the Weddell Sea polynya on biogeneous sedimentation seemed to be weakened.

Variations of atrnospheric $\mathrm{CO}_{2}$ during Pleistocene climatic cycles were possibly controlled by Southern Ocean productivity, such that more effective "biological pump mechanisms" during glacial times cause the Southern Ocean to be a sink for atmospheric $\mathrm{CO}_{2}[\mathrm{Keir}$ 1988]. Enhanced productivity during glacials should be caused by higher solar radiation and reduced circulation of surface waters [Sundquist and Broecker, 1985] or by increased atmospheric dust fallout which supplies iron to iron-limited Antarctic surface waters [Martin, 1990]. On the other hand, a reduced consumption of nutrients was postulated because of the extensive sea ice coverage during glaciations [Mix and Fairbanks, 1985]. This may result in an increasing amount of preformed nutrients in low latitudes which may enhance productivity there [Sarnthein et al., 1988].

The glacial sediments analyzed in this study with little or no biogenic components, reduced bioturbation, low IRD content and consisting mainly of mud clearly indicate strongly reduced productivity and sedimentation rates during glaciations in high southern latitudes around the Antarctic continent. This evidence is consistent with other recent studies, indicating low productivity in the Southern Ocean during glacial times [Labeyrie and Duplessy, 1985; Mackensen et al., 1989; Grobe et al., 1990b; Mortlock et al., 19911. Estimates of sea ice distribution during the last glacial maximurn show continuous ice coverage south of $60^{\circ} \mathrm{S}$ [ Hays, 1978; Cooke and Hays, 19821. During these times the availability of light in surface waters was strictly reduced by a snowcovered sea ice, which will have been the most significant factor limiting productivity in the Antarctic Ocean.

Glacial transport and supply of terrigenous sediments within the Antarctic Ocean are almost exclusively accomplished by rafting by icebergs. Transport by sea ice, an important sediment distribution process in the Arctic [Wollenburg, 19911, is missing owing to the absence of sediment supply by meltwater and rivers.

Two different types of icebergs in the Antarctic Ocean can be distinguished as a result of calving processes. Calving from glaciers, which is mainly a process of the Antarctic Peninsula, produces icebergs during most of a climatic cycle which transport a significant amount of sediment [Drewry and Cooper, 19811. The sediment is incorporated at their base or by sedirnentation on the glacier. However, in relation to the mass budget of the Antarctic ice sheet and the production of icebergs from ice shelves, icebergs calved frorn glaciers are subordi- nate. Nevertheless, they have to be taken into account when calculating the sediment supply to the ocean, particularly in the vicinity of the Antarctic Peninsula.

Calving from ice shelves produces the typical Antarctic tabular iceberg which is mostly free of any sediment load [Denton et al., 1971]. When the continental ice crosses the grounding line, after a short distance, ablation processes reach peak values. An ablation rate of up to $2 \mathrm{~m} / \mathrm{yr}$ was calculated below ice shelves close to the grounding line [Thomas,1973; Kipfstuhl, 1991]. The ice, lost at the base of the ice shelves, is partly replaced by the accumulation of snow on their surface. The basal debris load is lost rapidly on the way to the calving line or beyond. It is obvious that calving from broad ice shelves produces "clean" icebergs, almost free of any sedirnent load.

The NADW transports heat into the Antarctic Ocean. When the production of NADW is switched off during glacials, the lower water temperatures hamper basal melting of ice shelves. The coastal ice margins remain thicker, resulting in a seaward extension of the ice shelf and consequently in an increase of the grounded parts of the Antarctic ice sheet. The sediment load, incorporated at the base of the ice, will be transported further off the shelf and contributes to sedimentation on the slope.

Three transport processes by ice are possible around the East Antarctic Ice Sheet. The ice sheet is rnainly surrounded by ice shelves, delivering a significant amount of sediment to the sea; two of them are controlled by sea level variations and are thus directly coupled to global climatic change. These are as follows:

1. In the landward part of an ice shelf, parts of the coastline exist where the grounding line coincides with the calving line. These "islands" act as stabilizing pivots which contribute in controlling size and extension of the ice shelf (e.g., Figure 1: Cape Norvegia and ice rises). Icebergs calving close to such areas incorporate sorne detrital debris.

2. Falls in sea level during glaciations reduce the size of the ice shelves shifting seaward from the grounding line. When sea level is at its lowest, the grounding line may reach the shelf edge in sorne places. Subglacial sediments will be bulldozed down the slope by episodical movements of the ice edge or may melt out close to the grounding line and deliver sediment directly to the slope.

3. The rapid rise in sea level during the transition from glacial to interglacial causes large parts of the marginal ice sheet to lift up and thus become an ice shelf. A resulting increase in calving processes produces a large number of icebergs, which transport some shelf sediments, still frozen at their bases, to the deep sea.

The ice-rafted fraction of sediments in the investigation area is delivered by two processes. First, the petrographical composition of dropstones on the slope is mainly granitic, indicating its origin from East Antarctica. Icebergs frorn calving areas further away are 
driven by the Circum-Antarctic Current and, when entrained by the Weddell Gyre, deliver sediments from somewhere on the East Antarctic coast. Since the full cryospheric development of the Antarctic ice sheet, those icebergs may have contributed to ice rafting at any time during the late Neogene, irrespective of glacial or interglacial conditions. This granitic IRD signal is found in all sediment facies in varying amounts, producing the typical glaciomarine composition of the Antarctic Ocean sediments.

In contrast, close to the continent, the amount and composition of sediments is controlled by the ice streams and source rocks mainly of the hinterland of the investigation area, which are Jurassic basalts. Material from the adjacent coastal areas contributes to the continental margin sediments at all water depths but is most irnportant in shallower depths and close to the shelf. The sediments from the shelf are mainly responsible for the distinct and pronounced cycles in sediment composition on the upper slope. With increasing distance from the continent, the cyclicity becornes increasingly masked by pelagic sedirnentation. Variations of the detrital components are strongest during glacials (Figure 7).

From the observations above, it is inferred that the composition of the detrital mineral suites of the Antarctic continental margin sediments mainly depends on the petrographic nature of the source rocks. The source of the terrigenous detritus changes with processes and distance from the continent. Because the East Antarctic craton largely consists of crystalline rocks, mica-illite and some chlorite associated with quartz, feldspar, and various mafic minerals are the most frequent species in the clay fraction. An influence of the specific basic to ultrabasic source rocks in Queen Maud Land can be recognized only very close to the continent. As a result of the exclusively physical weathering processes, kaolinite occurs only in traces, and the amount of the nonlayered minerals in the clay fraction is much higher there than in lower latitudes.

The clay rnineral composition was found to be a sensitive indicator to changes in sediment transport. Each clay mineral is found in all facies but in varying arnounts. The ternary diagram of clay mineral composition shows that $20 \%$ illite, $10 \%$ chlorite, and $10 \%$ srnectite are minimum values in each facies (Figure 10). Clays are permanently delivered by current transport, as this is the only process which contributes to all facies. One mechanism responsible for changes in clay mineral composition appears to be dorninated by differential settling and thus grain size sorting, but the final composition is controlled by some contribution of all of the three main sediment-delivering processes: ice rafting, current transport, and gravitational movement downslope. During the different stages of climatic cycles, each of these processes is dominant at some time.

\section{SEDIMENTATION MODEL}

Interpretation of the late Pleistocene sediment sequence from the Antarctic continental slope can be used to synthesize a general relationship between sediment facies and paleoclimatic, paleoceanographic and paleoglacial conditions. We propose a model for glaciomarine sedimentation during glacial and interglacial stages, based on a stacked sedimentological record from the eastern Weddell Sea continental margin covering the last $300 \mathrm{kyr}$. Very similar records were found in all sediments between South Orkney $\left(45^{\circ} \mathrm{W}\right)$ and Gunnerus Ridge $\left(35^{\circ} \mathrm{E}\right)$, an area which covers roughly a third of the Antarctic coastline (Figure 1). Therefore we suggest that our sedimentation model (Figures 11 and 12), including distinct paleoenvironmental changes and different sedimentary processes, applies to most of East Antarctica and the Weddell Sea area.

The model fits best for the last four climatic cycles (stages 1 to 11). Typical of this time period are a pronounced 100-kyr periodicity, abrupt terminations of glacials, and a trend of decreasing $\delta^{18} \mathrm{O}$ values during interglacials when compared with Pleistocene data older than $420 \mathrm{kyr}$. However, our model may partly apply to early and middle Pleistocene deposits, although the cyclic changes of the global climate are generally less pronounced. This condition has a major influence on sea ice distribution during the southern summer.

\section{Glacial Termination and Peak Warm Interglacial}

The short transition frorn glacial to interglacial induces substantial changes in the sedimentary environment of the Antarctic Ocean. Several processes are triggered by two most important changes: the rise of sea level and the increasing contribution of NADW to the CDW.

The rising sea level causes the marginal parts of the Antarctic ice sheet to float, thereby producing broad, unstable ice shelves (Figure 11). The concurrent recession of the grounding line is sedimentologically identified on the shelf by the facies boundary between basal till and glacial-marine sediment [Anderson et al., 19801. $A$ reduced sea ice coverage close to the continent also contributes to destabilization, as does the warmer CDW, which provides heat for increased basal melting IPotter and Paren, 1985; Hodell and Ciesielski, 1990]. Within a very short geological time, the large ice shelves are increasingly reduced by intense calving processes. A large number of icebergs transport sediments, frozen at their base from the shelf contact, to the deep sea. This intense ice rafting is the main sedimentary process during the initial phase of an interglacial and is responsible for an increase in sedimentation rates by nearly an order of magnitude above those of glacial conditions. Sedimentation rates decrease slightly when ice shelves are reduced and glacial conditions and the mass budget of the ice sheet are more stable. 


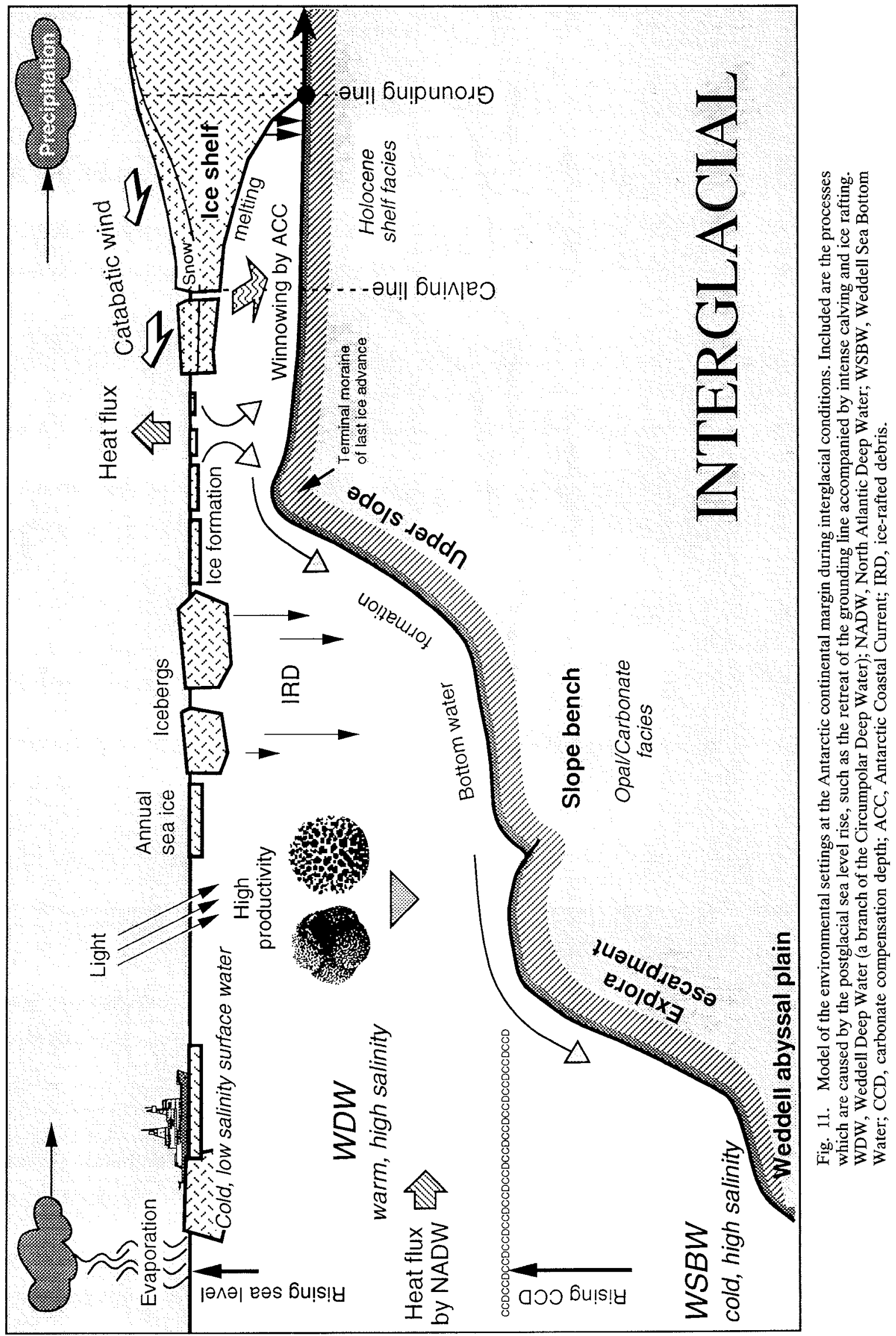


GROBE AND MACKENSEN: LATE QUATERNARY CLIMATIC CYCLES

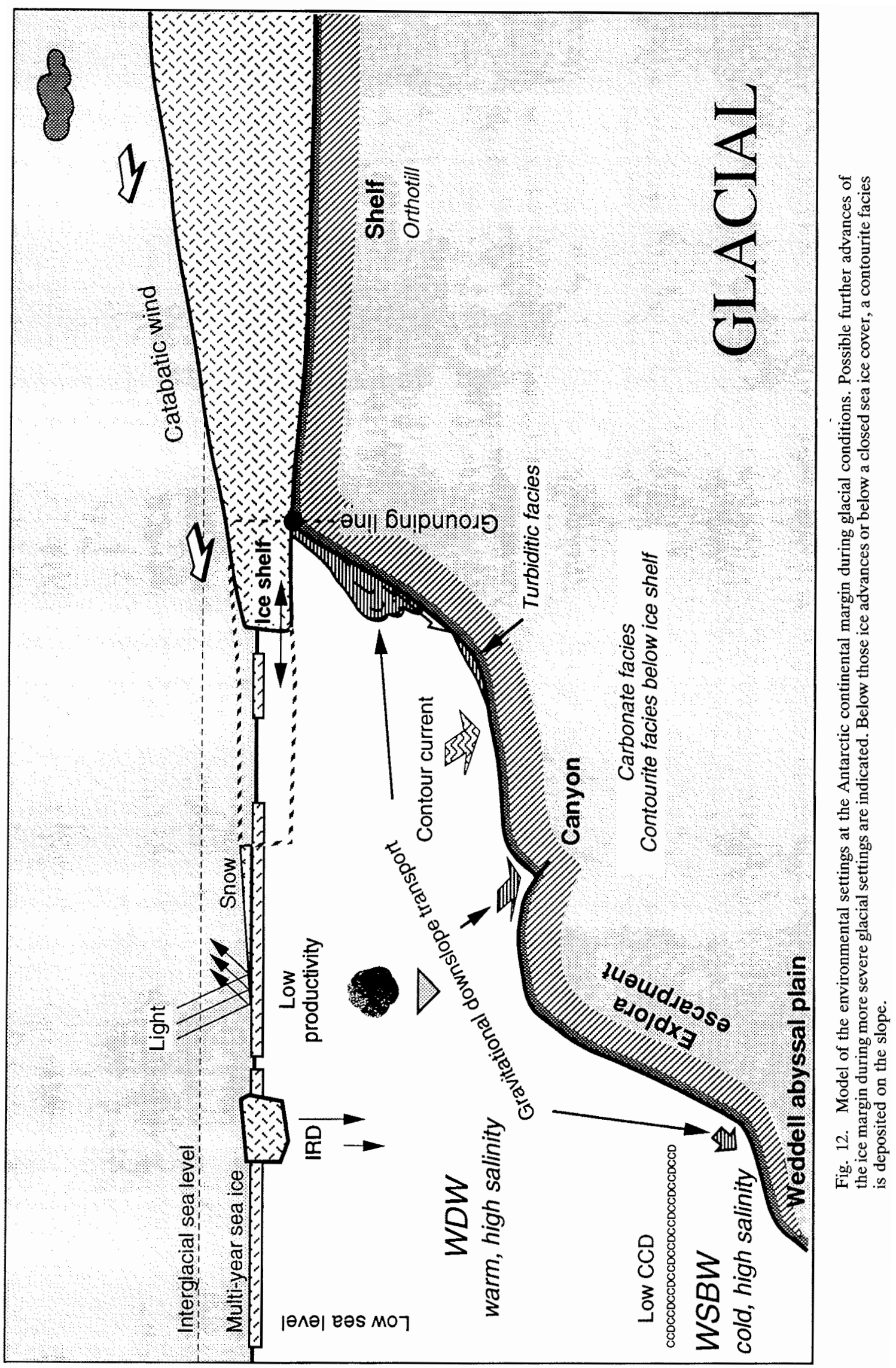


The contribution of NADW to Antarctic Ocean waters was much greater during interglacials than during glacials, at least over the past 550 kyr [e.g., Duplessy et al., 1988; Oppo et al., 19901. With the glacial termination, the production of NADW in the North Atlantic recommences, feeding water to the Antarctic Ocean, with a short time delay of about $1 \mathrm{kyr}$. An increase in the flux of NADW, a major source of heat and salt, also has profound consequences for sedimentation processes. The upwelling of warmer CDW promotes the retreat of sea ice in spring. With increasing availability of light in the surface waters, primary production increases to peak values and so favors the burial of a significant amount of siliceous microfossils. When there is high productivity in surface waters, N. pachyderma contributes substantially to the plankton. But the high input of organic matter to the deep water increases the $\mathrm{CO}_{2}$ content which, in turn, shoals the CCD. As a consequence, sediments of the peak warm intervals contain very few or no calcareous foraminifera (Figure 8). Additionally, higher export productivity favors secondary benthos activity, and consequently bioturbation is observed in sediment texture and grain size distribution (Figure 9).

The current regime at the continental margin became enhanced during peak warm times because the retreating continental ice edge and the reduction in sea ice favor wind-driven processes and oceanic circulation. Katabatic winds play an important role in the formation of coastal polynyas and hence sea ice formation above the shelf. This process, together with the increasing size of ice shelves, favors the formation of Ice Shelf Water (ISW), which flows down the slope thereby contributing to the formation of Weddell Sea Bottom Water (WSBW) [Foldvik and Gammelsrød, 1988]. These enhanced current activities are responsible for the deposition of relative coarse sediments, dominated by a coarse to medium silt. Very little clay contributes to the sedimentation, which there mainly consists of ice-rafted illite (Figure 10).

The response time of individual processes at the glacial termination differs. The lag of productivity might be only a few thousand years (3-5 kyr) and is dependent on the adjustment time of the oceanographic and sea ice conditions of the Antarctic Ocean. Close to the shelf break, the drastic changes in the terrigenous sedimentation stop when the postglacial ice shelves are reduced to a stable size. The retreat of the ice margin may last some thousand years.

The response time of those sedimentary processes which are directly linked to the mass budget and behavior of the Antarctic ice sheet rnight be longer (10-15 kyr). This can be observed by the general distribution of IRD in the slope sediments, which shows a significant delay in occurrence after glacial terminations and even after the following climatic optima (Figure 8). One explanation for the delayed response of specific sedi- rnentary processes might be the less sensitive behavior of the high southern latitude environment, where some glacial and hydrographic conditions may change more sluggishly and adjust to a changing climate with a time lag due to the presence of a huge ice sheet acting as a climatic buffer.

\section{Moderate Interglacial to Glacial Transition}

Toward the end of the interglacial warm period, the biogenic portion of the sediments changes from siliceous to calcareous microfossils. During a climatic cycle, large parts of the Antarctic Ocean are, for most of the time, continuously covered with ice, reducing the availability of light and hence primary production in the surface waters (Figure 12). The onset of calcareous sediment deposition in the Weddell Sea region is most probably linked to a decrease in the $\mathrm{CO}_{2}$ content of deepwater masses. Lower export productivity due to reduced photosynthesis in surface waters lowers the CCD to about $4000 \mathrm{~m}$ and allows carbonate in sediments above this depth to be preserved. There will still be seasonal variations of the sea ice, but they are presumably restricted to the northern marginal areas of the Antarctic Ocean. In this context, continuous ice coverage means the presence of sea ice throughout the year but does not mean closed ice conditions. Short-term changes in the amount and distribution of sea ice are locally influenced by the intensity of katabatic winds, tidal currents, seasonal climatic variations, and presumably local insolation.

During the transition from interglacial to glacial, a delayed response of the sedimentary processes to climatic deterioration must be considered. A high amount of clay and fine silt is delivered by ice calving and rafting. These processes still contribute intensively to sedimentation because of continuing ice flow that is a result of the increased mass of the ice sheet during the former interglacial. In contrast, there is a much more rapid response to climatic cooling in the processes controlling bottom water formation. The production of cold ice shelf water and thus bottom current activity becomes reduced by increasing sea ice coverage and the lowering of sea level, which diminishes the extent of the ice shelves. The result of the superimposition of both intense ice rafting and lowered bottom current velocity is the deposition of much higher amounts of fine fractions in the post warm period sediments (Figures 8 and 9). In addition, peak values of illite in the clay fraction indicate that the terrigenous detritus is mainly delivered by ice rafting. A higher proportion of coarse IRD is found only at the beginning of this climatic transition. IRD decreases with the onset of the glacial maxirna.

The composition of the facies deposited during the transition from moderate interglacial to early glacial conditions is quite similar. Only in this case, a decrease in carbonate content might indicate reduced productiv- 
ity because of enhanced sea ice conditions. Very close to the continent, increasing gravitational transport down the slope, triggered by the advancing ice edge, is responsible for a higher amount of coarse detritus, changes in the composition of clay mineralogy, and an increase in sedimentation rates. In contrast, sedimentation rates decrease on the lower slope.

\section{Glacial Maxima}

During extensive glaciations on the northern hemisphere the Antarctic ice sheet also expands aerially. Thus during Pleistocene time the ice margins oscillate across the entire continental shelf, and the grounding lines repeatedly coincide with the shelf edge (Figure 12). Expansion and grounding of ice shelves occur in parts of East Antarctica as well as West Antarctica and take place predominantly in areas with broad continental shelves. The expansion is caused by sea level lowering as the result of the buildup of large ice sheets on Scandinavia, Siberia and North America. Thus the Antarctic ice sheet is more indirectly coupled to global cooling through processes occurring in the northern hemisphere.

From the sedimentological interpretations, no direct information can be revealed about the total mass budget of the Antarctic ice sheet. New results from a computer simulation of the behavior of the continental ice during the last climatic cycle show that in addition to the extending ice shelves, the total ice volume increases by about $10^{16} \mathrm{~m}^{3}$ [Huybrechts, 19921. This result is consistent with earlier findings [i.e., Denton and Huges, 1981]. The model also shows that fluctuations are primarily driven by changes in eustatic sea level. This causal relationship implies that changes of the ice sheet depend on the magnitude and duration of the sea level depression during the final stage of a glacial period [Huybrechts, 1992].

During glacials, most of the Antarctic Ocean is covered with ice, and temperatures are lower. This ice cover results in less evaporation there, and consequently there is less snow precipitation and accumulation on the continent. On the basis of ${ }^{10} \mathrm{Be}$ concentrations in the Vostok ice core, it is concluded that precipitation rates in the Antarctic were roughly halved during the last glaciation [Yiou et al., 1985]. Even a thinning of the ice sheet has occurred in some areas [Andersen, 1990]. Furthermore, in the Transantarctic Mountains srnall local glaciers retreat during glacials, mainly because of changes in precipitation [Denton et al., 1991].

The sea level lowering during glacial maxima makes shelf sediments available for ice erosion and subsequent redistribution and sedimentation on the upper slope. Gravitational sediment transport is the most active mechanism during sea level lowstands. Canyon systems such as the Wegener Canyon, branching up to the shelf break, serve as preferred pathways for sediment transfer to the deep sea mainly by turbidity currents (Figure 12). Thus it was mainly during glacial episodes that deep-sea terrigenous sedimentation was strongly influenced by ice margin processes. As a result, depositional areas like the Weddell Fan [Anderson et al., 1986] are fed with sediments.

Reduced NADW and thus a diminished heat transfer into the CDW have consequences on the amount of melting of both sea ice and ice shelves. During harsh climatic conditions the sea ice cover may be closed and attached to the ice shelf. Snow, mainly collected and delivered by katabatic winds from the inland ice, accumulates on the sea ice. This process adds to the overall thickness of the thick, multiyear ice. Thick and stable sea ice conditions help to increase the size of the ice shelf areas by stabilization of their margins and protect them against weakening by waves. Further expansion and stabilization of ice shelves is also favored by cooler shelf water, inhibiting basal melting. All processes may cause further advances of the ice shelf edge, up to 100 $\mathrm{km}$ from the shelf break, producing a broad ice shelf above the slope. During such peak glacial conditions, contourites are deposited on the slope below the ice (Figures 9 and 12).

Acknowledgments. We acknowledge the assistance and excellent cooperation of $\mathrm{R} / \mathrm{V}$ Polarstern's crew and master during the cruises. The authors are thankful to Hans Hubberten and Gerhard Kuhn for discussions and providing laboratory conditions. Laboratory work was undertaken mainly with the assistance of Margret Meyer zu Uptrup and Susanne WiebeKawaletz. We thank Werner Ehrmann, Martin Melles, Mike Kendall, John Andrews, and an anonymous reviewer for improving the manuscript. Part of this work was supported by the Deutsche Forschungsgemeinschaft (grant Sp 296/1-1). This is publication 546 of the Alfred Wegener Institute for Polar and Marine Research and contribution 37 of the Sonderforschungsbereich 261 at Bremen University.

\section{REFERENCES}

Abelmann, A., R. Gersonde, and V. Spiess, PliocenePleistocene paleoceanography in the Weddell Sea-Siliceous microfossil evidence, in Geological History of Polar Oceans. Arctic Versus Antarctic, NATOIASI Ser. C, edited by U. Bleil and J. Thiede, pp. 729-759, Kluwer Academic Press, Dordrecht, Netherlands, 1990.

Andersen, B. G., Cenozoic glacier fluctuations in polar regions - Terrestrial records from Antarctica and the North Atlantic sector of the Arctic, in Geological History of Polen Oceans: Arctic Versus Antarctic, NATOIASI Ser. C, edited by $U$. Bleil and J. Thiede, pp. 245-254, Kluwer Academic Press, Dordrecht, Netherlands, 1990.

Anderson, J. B., The marine geology of the Weddell Sea, Ph.D. thesis, Contrib. 35, 222 pp., Fla. State Univ., Tallahassee, 1972.

Anderson, J. B., Factors controlling $\mathrm{CaCO}_{3}$ dissolution in the Weddell Sea from foraminiferal distribution Patterns, Mar. Geol. . 19, 315-332, 1975.

Anderson, J. B., D. D. Kurtz, and F. M. Weaver, Sedimentation on the Antarctic continental slope, in Geology of Con- 
tinental Slopes, Spec. Publ. Soc. Econ. Paleontol. Mineral., 27, 265-283, 1979.

Anderson, J. B., D. D. Kurtz, E. W. Domack, and K. M. Balshaw, Glacial and glacial marine sediments of the Antarctic continental shelf, J. Geol., 88, 399-414, 1980.

Anderson, J. B., S. B. Davis, E. W. Domack, D. D. Kurtz, K. M. Balshaw, and R. Wright, Marine sediment core descriptions, IWSOE 68, 69, 70, Deep Freeze 79, 60 pp., Rice Univ., Houston, Tex., 1981.

Anderson, J. B., C. Brake, E. W. Domack, N. C. Myers, and J. Singer, Sedimentary dynamics of the Antarctic continental margin, in Antarctic Earth Science, edited by R. L. Oliver, P. R. James, and J. B. Jago, pp. 387-389, Australian Academy of Science, Canberra, $1983 a$.

Anderson, J. B., C. Brake, E. W. Domack, N. C. Myers, and R. Wright, Development of a polar glacial-marine sedimentation model from Antarctic Quarternary deposits and glaciological information, in Glacial-Marine Sedimentation, edited by B. F. Molina, pp. 233-264, Plenum, New York, $1983 b$

Anderson, J. B., R. Wright, and B. Andrews, Weddell fan and associated abyssal plain, Antarctica: Morphology, sediment processes, and factors influencing sediment supply, Geo Mar. Lett., 6, 121-129, 1986.

Anderson, J. B., B. A. Andrews, L. R. Bartek, and E. M. Truswell, Petrology and palynology of Weddell Sea glacial sediments: Implications for subglacial geology, in Geological Evolution of Antarctica, edited by M. R. A. Thomson, J. A. Crame, and J. W. Thomson, pp. 231-235, Cambridge University Press, New York, 1991.

Andrews, B. A., Petrology of Weddell Sea glacial sediments: Implications for provenance and glacial history, Antarct. $\mathbf{J}$. 19, 92-94, 1984.

Barker, P. F., et al., Leg 113, Proc. Ocean Drill. Program Initial Rep., 113, 785 pp., 1988.

Barker, P. F., et al., Leg 113, Proc. Ocean Drill. Program Sci. Results, 1033 pp., 1990.

Berger, A. L., Long-term variations of caloric insolation resulting from the Earth's orbital elements, Quat. Res., 9, 139-167, 1978.

Berger, W. H., and J. S. Killingley, Glacial-Holocene transition in deep sea carbonates: Selective dissolution and the stable isotope signal, Science, 197, 563-566, 1977.

Brehme, I., Die Dokumentation der Bodenwasserstromung in den Sedimenten des nordwestlichen Weddell Meeres, Rep. Polar Res., 110, 92 pp., 1991.

Burckle, L. H., and N. Abrams, Regional Pliocene-early Pleistocene hiatuses in the Southern Ocean-Diatom evidence, Mar. Geol., 77, 207-218, 1987.

Carmack, E. C., and J. D. Foster, On the flow of water out of the Weddell Sea, Deep Sea Res., 22, 711-724, 1975.

Charles, C. D., and R. G. Fairbanks, Glacial to interglacial changes in isotopic gradients of Southern Ocean surface water, in Geological History of Polar Oceans: Arctic versus Antarctic, edited by U. Bleil and J. Thiede, pp. 729-760, NATOIASI Series C: Dordrecht, the Netherlands (Kluwer Academic Press), 1990.

Cook, D. W., and J. D. Hays, Estimates of Antarctic Ocean seasonal sea-ice cover during glacial intervals, in Antarctic Geoscience, edited by C. Craddock, pp. 1017-1025, University of Wisconsin Press, Madison, 1982.

Cordes, D., Sedimentologie und PalẪoomagnetian Sedimenten der Maudkuppe (NordÃ][stliche Weddellmeer), Rep. Polar Res., 71, 121 pp., 1990.

Corliss, B., Linkage of North Atlantic and Southern Ocean deep-water circulation during glacial intervals, Nature, 298, $458-460,1982$.

Crowley, T. J., and C. L. Parkinson, Late Pleistocene varia- tions in Antarctic sea ice, I, Effect of orbital insolation changes, Clim. Dyn., 3, 85-91, 1988.

Defelice, D. R., and S. W. Wise, Surface lithofacies, biofacies, and diatom diversity patterns as models for delineation of climatic change in the southeast Atlantic Ocean, Mar. Micropaleontol., 6, 29-70, 1981.

Denton, G. H., and T. J. Huges (Eds.), The Last Great Ice Sheets, 484 pp., John Wiley, New York, 1981.

Denton, G. H., R. L. Armstrong, and M. Stuiver, The late Cenozoic glacial history of Antarctica, in The Late Cenozoic Glacial Ages, edited by K. K. Turekian, pp. 267-306, Yale University Press, New Haven, Conn., 1971,

Denton, G. H., M. L. Prentice, and L. H. Burckle, Late Cenozoic history of the Antarctic ice sheet, in The Geology of Antarctica, edited by R. J. Tingley, pp. 365433, Oxford University Press, New York, 1991.

Dieckmann, G. S., M. Spindler, M. A. Lange, S. F. Ackley, and $\mathrm{H}$. Eicken, Antarctic sea ice: A habitat for the foraminifer Neogloboquadrina pachyderma, J. Foraminiferal Res., 21, 182-189, 1991

Domack, D. J., Sedimentology of glacial and glacial-marine deposits on the George V-Adelie continental shelf, East Antarctica, Boreas, I, 79-97, 1982.

Domack, D. J., J. B. Anderson, and D. D. Kurtz, Clast shape as an indicator of transport and depositional mechanisms in glacial marine sediments: George V continental shelf, Antarctica, J. Sediment. Petrol., 50, 813-820, 1980.

Drewry, D. J., and A. P. Cooper, Processes and models of Antarctic glaciomarine sedimentation, Ann. Glaciol., 2, 117$122,1981$.

Dunbar, R. B., Sediment trau experiments on the Antarctic continental margin, Antarct. J. U. S., 19, 70-71, 1984.

Duplessy, J. C., N. J. Shackleton, R. G. Fairbanks, L. Labeyrie, D. Oppo, and N. Kalles, Deepwater source variations during the last climatic cycle and their impact on the global deepwater circulation, Paleoceanography, 3, 343360, 1988.

Elverhøi, A., Evidence for a late Wisconsin glaciation of the Weddell Sea, Nature, 293, 641-642, 1981.

Elverhøi, A., and E. Roaldset, Glaciomarine sediments and suspended particulate matter, Weddell Sea shelf, Antarctica, Polar Res., 1, 1-21, 1983.

Foldvik, A., and T. Gammelsrød, Notes on Southern Ocean hydrography, sea-ice and bottom water formation, Palaeogeogr. Palaeoclimatol. Palaeoecol., 67, 3-17, 1988.

Foldvik, A., T. Gammelsr $\varnothing \mathrm{d}$, and T. Tørresen, Circulation and water masses on the southern Weddell Sea shelf, in Oceanology of the Antarctic Continental Shelf, Antarct. Res. Ser, vol. 43, edited by S. S. Jacobs, pp. 5-20, AGU, Washington, D. C., 1985.

FÃ $1 / 4 t$ tereD. K., Die Expedition Antarktis IV mit FS Polarstern 1985186, Rep. Polar Res., 33, 204 pp., 1987.

Futterer, D. K., Die Expedition Antarktis VI mit FS Polarstern 1987188, Rep. Polar Res., 58, 267 pp., 1988.

FÃ $1 / 4$ ttereID. K., Die Expedition Antarktis VIII mit FS Polarstern 198911990, Rep. Polar Res., 90, 231 pp., 1991.

F $\tilde{A}^{1 / 4 t}$ tererD. K., and M. Melles, Sediment patterns in the southern Weddell Sea: Filchner Shelf and Filchner Depression, in Geological History of Polar Oceans: Arctic Versus Antarctic, NATO/ASI Ser. C, edited by U. Bleil and J. Thiede, pp. 381401, Kluwer Academic Press, Dordrecht, Netherlands, 1990.

FÃ¹/4tereĐ. K., H. Grobe, and S. GrÃ $1 / 4$ ni@uaternary sediment patterns in the Weddell Sea: Relations and environmental conditions, Paleoceanography, 3, 551-561, 1988.

Futterer, D. K., G. Kuhn, and H. W. Schenke, Wegener Canyon bathymetrie and results from rock dredging near ODP sites 691-693, eastern Weddell Sea, Antarctica, Proc. Ocean Drill. Program Sci. Results, 113, 39-48, 1990. 
Grobe, H., SpÃatpleistozÃaSedimentationsprozesse am antarktischen Kontinentalhang vor Kapp Norvegia, Ã Istlich Weddell See, Rep. Polar Res., 27, 120 pp., 1986.

Grobe, H., A simple method for the determination of ice-rafted debris in sediment cores, Polarforschung, 57, 123-126, 1987.

Grobe, H., and G. Kuhn, Sedimentation processes at the Antarctic continental margin, in The Expedition Antarktis-IV of RV "POLARSTERN" 1985186, Rep. Polar Res., $33,80-84,1987$,

Grobe, H., D. K. FÃ $1 / 4$ ttererand V. Spiess, Oligocene to Quaternary processes on the Antarctic continental margin ODP Leg 113, Site 693, Proc. Ocean Drill. Program Sci. Results, 113, 121-131, 1990a.

Grobe, H., A. Mackensen, H.-W. Hubberten, V. Spiess, and D. K. FÃ $1 / 4$ ttere Stable isotope record and late Quaternary sedimentation rates at the Antarctic continental margin, in Geological Histoiy of Polar Oceans: Arctic Versus Antarctic, NATOIASI Ser. $C$, edited by $U$. Bleil and J. Thiede, pp. 539-572, Kluwer Academic Press, Dordrecht, Netherlands, $1990 b$

Haase, G. M., Glaciomarine sediments along the FilchnerRonne Ice Shelf, southern Weddell Sea-First results of the 198311984 Antarktis-I114 expedition, Mur. Geol., 72, $241-$ $258,1986$.

Hambrey, M. J., and P. J. Barrett, The Cenozoic sedimentary and climatic record from the Ross Sea region of Antarctica, in The Antarctic Paleoenvironment: A Perspective on Global Change, Part 2, Antarct. Res. Ser., edited by J. P. Kennet and D. A. Warnke, AGU, Washington, D, C., in press, 1992.

Hambrey, M. J., W. U. Ehrmann, and B. Larsen, Cenozoic glacial record of the Prydz Bay Continental Shelf, East Antarctica, Proc. Ocean Drill. Program Sci. Results, 119, 77-132, 1991.

Hayes, D. E., et al., Leg 28, Initial Rep. Deep Sea Drill. Proj., 28, 1017 pp., 1975.

Hays, J. D., A review of the late Quaternary climatic history of Antarctic seas, in Antarctic Glacial Histoiy and World Paleoenvironments, edited by Z. Bakker, pp. 57-71, 1978.

Henriet, J. P., and H. Miller, Some speculations regarding the nature of the Explora-Andenes Escarpment, Weddell Sea, in Geological Histoiy of Polar Oceans: Arctic Versus Antarctic, NATOIASI Ser. $C$, edited by $U$. Bleil and J. Thiede, pp. 163-169, Kluwer Academic Press, Dordrecht, Netherlands, 1990

Hinz, K., and W. Krause, The continental margin of Queen Maud Land/Antarctica: Seismic sequences, structural elements, and geological development, Geol. Jahrb., E23, 1741, 1982.

Hodell, D. A., and P. F. Ciesielski, Southern Ocean response to the intensification of northern hemisphere glaciation at 2.4 $\mathrm{Ma}$, in Geological History of Polar Oceans: Arctic Versus Antarctic, NATOIASI Ser. $C$, edited by $U$. Bleil and J. Thiede, pp. 707-728, Kluwer Academic Press, Dordrecht, Netherlands, 1990.

Hollister, C. D., and R. B. Eider, Contour currents in the Weddell Sea, Deep Sea Res., 16, 99-101, 1969.

Huybrechts, P., The Antarctic ice sheet and environmental change: A three-dimensional modelling study, Rep. Polar Res., 99, 241 pp., 1992.

Imbrie, J., J. D. Hays, D. G. Martinson, A. MacIntyre, A. C. Mix, J. Morley, N. G. Pisias, W. L. Prell, and N. J, Shackleton, The orbital theory of Pleistocene climate: Support from a revised chronology of the marine $\mathrm{d}^{8} 0$ record, in Milankovitch and Climate, edited by A. Berger, J. Imbrie, J. Hays, G. Kukla, and B. Saltzmann, pp. 269-305, D. Reidel, Hingham, Mass., 1984.

Juckes, L. M., The geology of north-eastern Heimefrontfjella, Dronning Maud Land, Br. Antarct. Surv. Sci. Rep., 65, 1-44, 1972.
Kaharoeddin, F. A., M. R. Eggers, E. H. Goldstein, R. S Graves, D. K. Watkins, J. A. Bergen, and S. C. Jones, ARA Islas Orcadas cruise 1578 sediment descriptions, Contrib. 48, Sediment. Res. Lab., Fla. State Univ,, Tallahassee, 1980.

Kaul, N., Detaillierte seismische Untersuchungen am Ãdstliche Kontinentalrand des Weddell-Meeres vor Kapp Norvegia, Antarktis, Rep. Polar Res., 89, 120 pp., 1991.

Kellogg, T. B., and D. E. Kellogg, Antarctic cryogenic sediments: Biotic and inorganic facies of ice shelf and marinebased ice sheet environrnents, Palaeogeogr. Palaeoclimatol Palaeoecol., 67, 51-74, 1988.

Kellogg, T. B., R. S. Truesdale, and L. E. Ostermann, Late Quaternary extent of the West Antarctic Ice Sheet: New evidence from the Ross Sea cores, Geology, 7, 249-253, 1979.

Keir, R. S., On the late Pleistocene ocean geochemistry and circulation, Paleoceanography, 3, 413-445, 1988.

Kipfstuhl, J., Zur Entstehung von Unterwassereis und das Wachstum und die Energiebilanz des Meereises in der Atka Bucht, Antarktis, Rep. Polar Res., 85, 88 pp., 1991.

Kroopnick, P., The distribution of ${ }^{13} \mathrm{C}$ of $\Sigma \mathrm{CO}_{2}$ in the world oceans, Deep Sea Res., 32, 57-84, 1985.

Kuhn, G., W. Ehrmann, M. Hambrey, M. Melles, and G. Schmiedl, Glacio-marine sedimentary processes in the Weddell Sea and Lazarev Sea, in Die Expeditionen ANTARKTIS IX/1-4 des Forschungsschiffes 'Polarstern' 1990191, Rep. Polar Res., 100, 223-244, 1992.

Labeyrie, L. D., and J. C. Duplessy, Changes in the oceanic ${ }^{13} \mathrm{C}^{12} \mathrm{C}$ ratio during the last 140000 years: high-latitude surface water records, Palaeogeogr. Palaeoclimatol. Palaeoecol., 50, 217-240, 1985.

Ledbetter, M. T., and P. F. Ciesielski, Post-Miocene disconformities and paleoceanography in the Atlantic sector of the Southern Ocean, Palaeogeogr. Palaeoclimatol. Palaeoecol., 52, 185-214, 1986.

Mackensen, A., H. Grobe, H.-W. Hubberten, V. Spiess, and D. K. Futterer, Stable isotope stratigraphy from the Antarctic continental margin during the last one million years, Mar. Geol, 87, 315-321, 1989,

Mackensen, A., H. Grobe, G. Kuhn, and D. K. FÃ $1 / 4$ tterer Benthic foraminiferal assemblages from the eastern Weddell Sea between 68 and $73^{\circ} \mathrm{S}$ : Distribution, ecology and fossilization potential, Mar. Micropaleontol., 16, 241-283, 1990.

Martin, J. H., Glacial-interglacial $\mathrm{CO}_{2}$ change: The iron hypothesis, Paleoceanography, 5, 1-13, 1990

Martinson, D. G., N. G. Pisias, J. D. Hays, J. Imbrie, T. C. Moore, Jr., and N. J. Shackleton, Age dating and the orbital theory of the Ice Ages: Development of a high-resolution 0 to 300,000-year chronostratigraphy, Quat. Res., 27, 1-29, 1987.

Melles, M., Pal ̃̃óoglaziologi und PalÃăozeanographi im Spätquart Ã đam Kontinentalrand des s $\tilde{A}^{1 / 4} /$ dlicheWeddellmeeres, Antarktis, Rep. Polar Res., 81, 190 pp., 1991

Miller, H., and H. Oerter, Die Expedition Antarktis V mit FS Polarstern 1986187, Bericht von den Fahrtabschnitten ANT V/4-5, Rep. Polar Res., 57, 1-57, 1990.

Miller, H., J. P. Henriet, N. Kaul, and A. Moons, A fine-scale seismic stratigraphy of the eastern margin of the Weddell Sea, in Geological Histoiy of Polar Oceans: Arctic Versus Antarctic, NATOIASI Ser. C, edited by U. Bleil and J. Thiede, pp. 131-161, Kluwer Academic Press, Dordrecht, Netherlands, 1990

Mix, A. C., and R. G. Fairbanks, North Atlantic surface-ocean control for Pleistocene deep-ocean circulation, Earth Planet. Sci. Lett., 73, 231-243, 1985.

Mortlock, R. A., C. D. Charles, P. N. Froelich, P. Zibello, J. Saltzman, J. D. Hays, and L. H. Burckle, Evidence for lower productivity in the Antarctic Ocean during the last glaciation, Nature, 351, 220-222, 1991.

Oppo, D. W., and R. G. Fairbanks, Variability in the deep and 
intermediate water circulation of the Atlantic Ocean during the past 25,000 years: Northern Hemisphere modulation of the Southern Ocean, Earth Planet. Sci. Leu., 86, 1-15, 1987.

Oppo, D. W., R. G. Fairbanks, A. L. Gordon, and N. J. Shackleton, Late Pleistocene Southern Ocean $d^{13} \mathrm{C}$ variability, Paleoceanography, 5, 43-54, 1990.

Orheim, O., and A. Elverh $\varnothing$ i, Model for submarine glacial deposition, Ann. Glaciol., 2, 123-128, 1981.

Oskierski, W., Verteilung und Herkunft glazial-mariner GerÃfll am Antarktischen Kontinentalrand des Ãd[stliche Weddellmeeres, Rep. Polar Res., 47, 132 pp., 1988.

Peters, M., Die Vulkanite im westlichen und mittleren Neuschwabenland, Vestfjella und Ahlmannryggen, Antarktika, Rep. Polar Res., 61, 186 pp., 1989.

Potter, J. R., and J. G. Paren, Interaction between ice shelf and ocean in George VI sound, Antarctica, in Oceanology of the Antarctic Continental Shelf, Antarct. Res. Sei'., vol. 43, edited by S. S. Jacobs, pp. 35-58, AGU, Washington, D. C., 1985.

Prell, W. L., J. Imbrie, D. G. Martinson, J. J. Morley, N. G. Pisias, N. J. Shackleton, and H. F. Streeter, Graphic correlation of oxygen isotope stratigraphy application to the late Quaternary, Paleoceanography, 1, 137-162, 1986.

Pudsey, C. J., P. F. Barker, and N. Hamilton, Weddell Sea abyssal sediments: A record of Antarctic bottom water flow, Mar. Geol., 81, 289-314, 1988.

Rex, D. C., Age of dolerite from Dronning Maud Land, $B r$. Antarct. Surv. Bull., 11, 101, 1967.

Ruddiman, W. F., M. E. Raymo, D. G. Martinson, B. M. Clement, and J. Backman, Pleistocene evolution of northern hemisphere climate, Paleoceanography, 4, 353-412, 1989.

Sarnthein, M., K. Winn, J.-C. Duplessy, and M. R. Fontugne, Global variations of surface ocean productivity in low and mid latitudes: Influence on $\mathrm{CO}_{2}$ reservoirs of the deep ocean and atmosphere during the last 21,000 years, Paleoceanography, 3, 361-399, 1988.

Savin, S. M., and R. G. Douglas, Stable isotope and magnesium geochemistry of recent planktonic foraminifera from the Southern Pacific, Geol. Soc. Am. Bull., 84, 2327-2342, 1973.

Singer, J. K., and J. B. Anderson, Use of total grain-size distributions to define bed erosion and transport for poorly sorted sediment undergoing simulated bioturbation, Mar. Geol., 57, 335-359, 1984.

Sundquist, E. T., and W. S. Broecker (Eds.), The Carbon Cycle and Atmospheric $\mathrm{CO}_{2}$ : Natural Variations Archean to Present, Geophys. Monogr. Ser., vol. 32, 627 pp., AGU, Washington, D. C., 1985.

Thomas, R. H., The dynamics of the Brunt Ice Shelf, Coats Land, Antarctica, Br. Antarct. Surv. Sci. Rep., 79, 1973.

Voss, J., Zoogeographische und Gemeinschaftsanalyse des Makrozoobenthos des Weddellmeeres (Antarktis), Rep. Polar Res., 45, 130 pp., 1988.

Weaver, F., Pliocene paleoclimatic and paleoglacial history of East Antarctica recorded in deep-sea piston cores, Contrib. 36, Sediment. Res. Lab., Fla. State Univ., Tallahassee, 1973.

Wefer, G., G. Fischer, D. K. Fütterer, R. Gersonde, S. Honjo, and D. Ostermann, Particle Sedimentation and productivity in Antarctic waters of the Atlantic sector, in Geological History of Polar Oceans: Arctic Versus Antarctic, NATOl ASI Ser. C, edited by $U$. Bleil and J. Thiede, pp. 363-379, Kluwer Academic Press, Dordrecht, Netherlands, 1990.

Wollenburg, I., Sedimenttransport durch das arktische Meereis, Ph.D. thesis, 132 pp., Univ. of Kiel, Kiel, Germany, 1991.

Wright, R., and J. B. Anderson, The importance of sediment gravity flow to sediment transport and sorting in a glacial marine environment: Eastern Weddell Sea, Antarctica, Geol. Soc. Am. Bull., 93, 951-963, 1982.

Wu, G., J. C. Herguera, and W. H. Berger, Differential dissolution: Modification of late Pleistocene oxygen isotope records in the western equatorial Pacific, Paleoceanography, 5, 581-594, 1990.

Yiou, F., G. M. Raisbeck, D. Bourles, C. Lorius, and N. I. Barkov, ${ }^{10} \mathrm{Be}$ in the ice at Vostok, Antarctica during the last climatic cycle, Nature, 316, 616-617, 1985.

Zwally, H. J., J. C. Comiso, D. L. Parkinson, W. J. Campbell, F. D. Carsey, and P. Gloersen, Antarctic sea ice, 1973-1976: Satellite passive microwave observation, NASA Spec. Publ., SP-459, 206 pp., 1983.

(Received August 25, 1991; accepted June 1, 1992.) 